\title{
Subunit- and Pathway-Specific Localization of NMDA Receptors and Scaffolding Proteins at Ganglion Cell Synapses in Rat Retina
}

\author{
Jun Zhang and Jeffrey S. Diamond \\ Synaptic Physiology Section, National Institute of Neurological Disorders and Stroke, National Institutes of Health, Bethesda, Maryland 20892-3701
}

Retinal ganglion cells (RGCs) receive excitatory glutamatergic input from ON and OFF bipolar cells in distinct sublaminae of the inner plexiform layer (IPL). AMPA and NMDA receptors (AMPARs and NMDARs) mediate excitatory inputs in both synaptic layers, but specific roles for NMDARs at RGC synapses remain unclear. NMDARs comprise NR1 and NR2 subunits and are anchored by membraneassociated guanylate kinases (MAGUKs), but it is unknown whether particular NR2 subunits associate preferentially with particular NR1 splice variants and MAGUKs. Here, we used postembedding immunogold electron microscopy techniques to examine the subsynaptic localization of NMDAR subunits and MAGUKs at ON and OFF synapses onto rat RGCs. We found that the NR2A subunit, the NR1C2' splice variant, and MAGUKs PSD-95 and PSD-93 are localized to the postsynaptic density (PSD), preferentially at OFF synapses, whereas the NR2B subunit, the NR1C2 splice variant, and the MAGUK SAP102 are localized perisynaptically, with NR2B exhibiting a preference for ON synapses. Consistent with these anatomical data, spontaneous EPSCs (sEPSCs) recorded from OFF cells exhibited an NMDAR component that was insensitive to the NR2B antagonist Ro 25-6981. In ON cells, sEPSCs expressed an NMDAR component, partially sensitive to Ro 25-6981, only when glutamate transport was inhibited, indicating perisynaptic expression of NR2B NMDARs. These results provide the first evidence for preferential association of particular NR1 splice variants, NR2 subunits, and MAGUKs at central synapses and suggest that different NMDAR subtypes may play specific roles at functionally distinct synapses in the retinal circuitry.

\section{Introduction}

NMDA receptors (NMDARs) are heterotetramers usually comprising two NR1 subunits and two NR2 subunits. NR1 subunits derive from a single gene that is spliced to produce functional variants (Zukin and Bennett, 1995), whereas NR2 subunits (NR2A-2D) arise from four different genes (Ishii et al., 1993; Monyer et al., 1994; Dingledine et al., 1999). NR1 subunits are required for proper receptor assembly and trafficking (McIlhinney et al., 1998, 2003), but NR2 subunits may dictate specific localization in the plasma membrane to synaptic or extrasynaptic sites (Stocca and Vicini, 1998; Rumbaugh and Vicini, 1999; Momiyama, 2000; Steigerwald et al., 2000). At most synapses, the NR2 subunit composition of synaptic and extrasynaptic receptors remains unclear, and it is unknown whether different NR1 splice variants also exhibit distinct localization patterns, or whether they coassemble specifically with particular NR2 subunits.

This work was supported by the National Institute of Neurological Disorders and Stroke (NINDS) Intramural Research Program. We thank Drs. Pierre Brown and Charles Gerfen for performing CTB injections; Drs. Brian Andrews, Christine Winters, Natalia Pivovarova, and Christine Brantner for help with freeze substitution; the NINDS LM and EM facilities for microscopy assistance; Drs. William Grimes and Annalisa Scimemi for experimental and analytical advice and assistance; and Dr. Christopher Thomas for comments on this manuscript.

Correspondence should be addressed to Dr. Jeffrey S. Diamond, Synaptic Physiology Section, National Institute of Neurological Disorders and Stroke/National Institutes of Health, 35 Convent Drive, Building 35, Room 3C-1000, Bethesda, MD 20892-3701. E-mail: diamondj@ninds.nih.gov.

DOI:10.1523/JNEUROSCI.5602-08.2009

Copyright $\odot 2009$ Society for Neuroscience $\quad$ 0270-6474/09/294274-13\$15.00/0
Membrane-associated guanylate kinases (MAGUKs), PSD95, PSD-93, SAP102, and SAP97, coordinate trafficking, anchoring, and signaling of receptors and ion channels via binding interactions in the cytoplasm (Kennedy, 1995; Kornau et al., 1995; Kim and Sheng, 2004). Like NR2 subunits, MAGUKs exhibit distinct subsynaptic expression patterns (Müller et al., 1996; Migaud et al., 1998; Valtschanoff et al., 1999; El-Husseini et al., 2000; Sans et al., 2000; Aoki et al., 2001; Davies et al., 2001; Kim and Sheng, 2004), but it is unclear whether particular NMDAR subunits associate preferentially with specific MAGUKs (Sans et al., 2000; Al-Hallaq et al., 2007) to direct subsynaptic targeting of particular NMDAR subtypes.

In the retina, synaptic excitation of retinal ganglion cells (RGCs) is mediated postsynaptically by NMDARs and AMPA receptors (AMPARs) (Mittman et al., 1990; Matsui et al., 1998; Chen and Diamond, 2002). Although NMDARs have been shown to contribute to synaptic plasticity and excitotoxicity elsewhere in the CNS (Collingridge and Lester, 1989), specific functional roles for NMDARs in the retina have not been determined. At RGC synapses in rat, physiological and anatomical evidence suggests that NMDARs are excluded from the postsynaptic density (PSD) and expressed perisynaptically (Chen and Diamond, 2002; Zhang and Diamond, 2006) [but see Hartveit et al. (1994) and Fletcher et al. (2000)]. Recent physiological work in mouse retina suggests that subsynaptic localization may depend on functional input layer (Sagdullaev et al., 2006). Here, we have examined the expression of NR1 splice variants, NR2 subunits, and MAGUKs at retrogradely labeled RGC postsynaptic pro- 
cesses in the ON and OFF layers of rat retina using postembedding immunogold electron microscopy (EM). We find that NMDARs are localized primarily perisynaptically in the ON layer and within the PSD in the OFF layer. NR2B-containing NMDARs are more prevalent at ON synapses than at OFF synapses, in contrast to NR2A NMDARs, which are more prevalent at OFF synapses. We also observe strong correlations between specific NR1 splice variants, NR2 subunits, and MAGUKs, suggesting that specific interactions between these synaptic proteins may underlie subsynaptic expression patterns in RGCs. Accordingly, spontaneous EPSCs (sEPSCs) recorded from RGCs confirm that NR2 subunit expression and subsynaptic localization underlie distinct physiological and pharmacological characteristics of ON and OFF synapses. These results suggest that different NMDAR subtypes may play specific roles in visual signaling in the retina.

\section{Materials and Methods}

Tissue preparation. Care and handling of animals were in accordance with National Institutes of Health (NIH) Animal Care and Use Committee guidelines. Retinal tissue for light microscopy (LM) study was prepared as described previously (Zhang and Diamond, 2006). Briefly, postnatal day 20 (P20) Sprague Dawley rats were deeply anesthetized with halothane and decapitated, and eyes were removed and hemisected. Eyecups then were fixed in $4 \%$ paraformaldehyde in $0.1 \mathrm{M}$ phosphate buffer (PB) at $\mathrm{pH} 7.4$ for $20-30 \mathrm{~min}$ at room temperature (RT). After several washes in $0.1 \mathrm{~m}$ PBS (PBS, pH 7.4), the eyecups were cryoprotected with graded sucrose solutions at $4^{\circ} \mathrm{C}(60 \mathrm{~min}$ each in $15 \%, 20 \%$, and $30 \%$, then overnight in $30 \%$ ). The tissue was embedded in OCT compound (Tissue Tek), vertically sectioned at $14 \mu \mathrm{m}$ on a cryostat, and collected on chrome-gelatin-coated glass slides. Additionally, rat cerebellum tissue also was prepared as described previously (Thompson et al., 2000). P20 rats were deeply anesthetized with halothane and were perfused through the aorta with $0.9 \%$ saline for $1 \mathrm{~min}$, followed by $4 \%$ paraformaldehyde in $0.1 \mathrm{M} \mathrm{PB}$ for $15-20 \mathrm{~min}$. Following fixations, the cerebellum was quickly removed from the skull and cryoprotected. The tissue was horizontal and coronally sectioned $(20 \mu \mathrm{m})$ on a cryostat, and collected on chrome-gelatin-coated glass slides.

Retinal tissue for postembedding immunogold EM was obtained from three blocks used in our previous work (Zhang and Diamond, 2006). Briefly, three P15 Sprague Dawley rats were anesthetized with pentobarbital and immobilized in a stereotaxic frame. Cholera toxin B subunit (CTB, 1-1.2\%; List Biological Laboratories) was injected bilaterally into the superior colliculus ( $2 \mu \mathrm{l}$ each site), one of the two main targets of mammalian RGC axons, to label RGCs and their dendrites, as described previously (Zhang and Diamond, 2006). Five to seven days following the injection, animals were deeply anesthetized with halothane and decapitated, and both eyes were removed and hemisected. Retinas were isolated, immediately cut into 100 - to 200 - $\mu \mathrm{m}$-thick strips, and subjected to $\mathrm{pH}$-shift fixation [in 4\% paraformaldehyde in $0.1 \mathrm{M} \mathrm{PB}$ at $\mathrm{pH} 6.0$ for $20-30 \mathrm{~min}$ and then in $4 \%$ paraformaldehyde plus $0.01 \%$ glutaraldehyde at $\mathrm{pH} 10.5$ for $10-20 \mathrm{~min}$ at RT; also see the study by Sassoè-Pognetto and Ottersen (2000)]. After several washes in PB with $0.15 \mathrm{~mm} \mathrm{CaCl}_{2}(\mathrm{pH}$ 7.4 at $4^{\circ} \mathrm{C}$ ), the tissue was cryoprotected with glycerol (60 min each in $10 \%, 20 \%, 30 \%$, then overnight in $30 \%$ ) in $0.1 \mathrm{M} \mathrm{PB}$, and rapidly frozen in liquid propane at $-190^{\circ} \mathrm{C}$ (Leica EM CPC). The tissue was then transferred into a freeze-substitution device (Leica EM AFS) and treated with $0.5 \%$ uranyl acetate in $100 \%$ methanol at $-90^{\circ} \mathrm{C}$ for $36 \mathrm{~h}$, after which the temperature was increased stepwise to $-45^{\circ} \mathrm{C}$. Samples were washed several times in precooled methanol and progressively infiltrated with Lowicryl HM20 resin (Electron Microscopy Sciences) (1:1 Lowicryl to methanol, 2 h; 2:1 Lowicryl to methanol, 2 h; 100\% Lowicryl, 2 h; 100\% Lowicryl, overnight) at $-45^{\circ} \mathrm{C}$. Finally, samples were polymerized $\left(-45^{\circ} \mathrm{C}\right.$ to $\left.0^{\circ} \mathrm{C}\right)$ with ultraviolet light for $40 \mathrm{~h}$ and then at RT overnight.

Primary antibodies. Antibodies used in this study have been characterized previously in rat retina by Western blot and immunocytochemistry (ICC; see references below). Polyclonal antibodies directed toward
NMDAR subunits (NR1C2, NR1C2', NR2A, and NR2B) were purchased from Millipore Bioscience Research Reagents. Anti-NR1C2 (catalog \#AB1516) recognizes splice variants $1 \mathrm{a}, 1 \mathrm{~b}, 2 \mathrm{a}$, and $2 \mathrm{~b}$, whereas antiNR1C2' (catalog \#AB5050P) recognizes splice variants 3a, 3b, 4a, and 4b (Hollmann et al., 1993; Blahos and Wenthold, 1996). Anti-NR2A (cata$\log \#$ AB1555P) and anti-NR2B (catalog \#AB1557P) were raised in rabbit against an affinity-purified C-terminal fusion protein with different amino acid sequences. These four antibodies recognize a band at $\sim 116$ $\mathrm{kDa}$ for NR1C2, $\sim 120 \mathrm{kDa}$ for NR1C2', $170 \sim 180 \mathrm{kDa}$ for NR2A, and $\sim 180 \mathrm{kDa}$ for NR2B (Goebel et al., 1998; Fletcher et al., 2000; Gründer et al., 2000; Kalloniatis et al., 2004). We did not examine expression of NR2C or NR2D, due to concerns about antibody specificity. Antibodies against MAGUK proteins (PSD-95, PSD-93, SAP102, and SAP97) were purchased from Affinity Bioreagents. Monoclonal anti-PSD-95 (catalog \#MA1-046) was raised in mouse against a purified recombinant rat PSD-95 and recognizes a band at $\sim 95 \mathrm{kDa}$ (Kornau et al., 1995; Koulen et al., 1998; Koulen, 1999). Polyclonal anti-PSD-93 (catalog \#PA1-043), anti-SAP97 (catalog \#PA1-741), and anti-SAP102 (catalog \#PA1-045) were raised in rabbit and recognize a band at $\sim 110 \mathrm{kDa}, \sim 140 \mathrm{kDa}$, and $\sim 102 \mathrm{kDa}$, respectively, and have been characterized by ICC and Western blot (Müller et al., 1995, 1996; Brenman et al., 1996; Aoki et al., 2001; Davies et al., 2001). Polyclonal goat anti-CTB (List Biological Laboratories) has been characterized in rat retina by ICC (Rivera and Lugo, 1998; Zhang and Diamond, 2006). Monoclonal anti-Calbindin D-28 (Millipore Bioscience Research Reagents), a marker for cerebellum Purkinje cells, has been characterized previously by ICC (Andressen et al., 1993; Thompson et al., 2000).

LM immunofluorescence. Before immunogold labeling for electron microscopy, antibody staining was examined using LM, as described previously (Zhang and Diamond, 2006). Slides were rinsed in PBS, blocked in $5 \%$ normal donkey serum (NDS, Sigma) in PBS for $1 \mathrm{~h}$ and incubated overnight in primary antibodies of polyclonal anti-rabbit NMDAR subunits (NR1C2 1:30, NR1C2' 1:100, NR2A 1:100, and NR2B 1:60) or anti-MAGUK proteins (PSD-95 1:200, PSD-93 1:100, SAP102 1:150, and SAP97 1:100) in 2\% NDS plus $1 \%$ bovine serum albumin (BSA, Sigma) with $0.3 \%$ Triton X-100 at RT for anti-NMDAR antibodies and at $4^{\circ} \mathrm{C}$ for others. After rinsing, sections were incubated for $2 \mathrm{~h}$ at RT in Cy3- or FITC-conjugated donkey anti-rabbit $\operatorname{IgG}(1: 400$ and 1:100, respectively) or Cy3-conjugated anti-mouse IgG (1:400). All fluorescent secondary antibodies were purchased from Jackson ImmunoResearch Laboratories. Slides were rinsed and coverslipped with Vectashield (Vector). Immunofluorescence was visualized with a confocal laser scanning microscope (Zeiss LSM-510) through $25 \times$ and $63 \times$ oil objectives. Brightness and contrast of the final images were adjusted in Adobe Photoshop 6.0.

Postembedding immunogold labeling. Postembedding immunogold ICC (EM) was performed on tissue taken from retinas retrogradely labeled with CTB to identify RGC process in the inner plexiform layer (IPL) (Zhang and Diamond, 2006). Briefly, oriented $\sim 70$-nm-thick ultrasections were collected on Formvar-Carbon coated nickel-slot grids. Grids were washed with distilled $\mathrm{H}_{2} \mathrm{O}$ followed by a Tris-buffered saline wash (TBS: $0.05 \mathrm{~m}$ Tris buffer, $0.7 \% \mathrm{NaCl}, \mathrm{pH} 7.6$ ), incubated in $5 \% \mathrm{BSA}$ in TBS for $30 \mathrm{~min}$, and then incubated overnight at RT in goat anti-CTB (1:3000) and an antibody to one NMDAR subunit (NR1C2 1:10, NR1C2' 1:50, NR2A 1:50, and NR2B 1:30) or one MAGUK protein (PSD-95 1:100, PSD-93 1:50, SAP102 1:80, and SAP97 1: 50) in TBS-Triton (0.01\% Triton X-100 in TBS, pH 7.6) with $2 \%$ BSA and $0.02 \mathrm{M} \mathrm{NaN}_{3}$ overnight at RT. Grids were washed with TBS, pH 7.6, for $30 \mathrm{~min}$, followed by TBS, pH 8.2, for $5 \mathrm{~min}$. Grids were then incubated in a mixture of donkey anti-goat IgG (1:20) coupled to 15 or $18 \mathrm{~nm}$ gold particles and donkey anti-rabbit IgG (1:20) or donkey anti-mouse IgG (1:20) coupled to $10 \mathrm{~nm}$ gold particles (Electron Microscopy Sciences) in TBS-Triton, $\mathrm{pH} 8.2$, with $2 \% \mathrm{BSA}$ and $0.02 \mathrm{M} \mathrm{NaN}_{3}$. Following washes in TBS, pH 7.6, for $30 \mathrm{~min}$, grids were washed in ultrapure $\mathrm{H}_{2} \mathrm{O}$ and dried. Grids were counterstained with $5 \%$ uranyl acetate and $0.3 \%$ lead citrate in distilled $\mathrm{H}_{2} \mathrm{O}$ for 8 and $5 \mathrm{~min}$, respectively.

In a subset of experiments, ultrathin sections were triple-labeled with antibodies to CTB (1:3000), NR2A (1:50), and PSD-95 (1:100), then by a mixture of IgGs coupled to 15,10 , and $5 \mathrm{~nm}$ gold particles, respectively, as described previously (Zhang and Diamond, 2006). 
Grids were viewed on a JEOL 1200 EM and images were digitalized. Final figures were processed only for brightness and contrast and annotations were added in Adobe Photoshop 6.0.

Specificity controls. The specificity of antibodies, immunofluorescence, and immunogold staining was tested several ways. First, preadsorption controls were performed at the LM level to confirm that each antibody was specific to its targeted antigen. When polyclonal antibodies to NMDARs and MAGUK proteins were preadsorbed with the polypeptide fragments or the fusion proteins (NMDAR subunits from Millipore Bioscience Research Reagents, MAGUK proteins from Affinity Bioreagents), no fluorescence was detected (Fig. $1 I-L$ ). Second, single or double labeling at the LM and EM level always was accompanied by control experiments in which one or two primary antibodies were eliminated and then the two or three appropriate secondary antibodies were applied in double or triple labelings. In these cases, only fluorescence or gold specific for the remaining primary antibody was detected (data not shown). Third, to confirm specificity of the NR2A antibody, double labelings (Calbindin D-28k 1:200 + NR2A 1:60, Calbindin D-28k + NR2B 1:60, and Calbindin D-28k + NR1C2' 1:60) were performed on cryosections of rat cerebellum, where Purkinje cells were immunopositive for NR2B and NR1C2' but immunonegative for NR2A (Fig. $1 \mathrm{M}, N$ ), consistent with previous results (Petralia et al., 1994; Thompson et al., 2000). Fourth, only very low EM immunogold densities (mean \pm SE, number of gold particles per linear micrometer) for antibodies to NMDAR subunits and MAGUK proteins were detected in RGC dendritic mitochondrial membranes compared with plasma membranes (see Figs. $5 D, 8 D)$.

Quantitative anatomical analysis. Ultrathin sections containing the full depth of the IPL were photomontaged at $25,000 \times$ magnification. For each section, 15 images spanning the full depth of the IPL were numbered in order from the inner edge of the inner nuclear layer to the outer edge of the RGC layer, and a total of 600 images $(40$ rows $\times 15)$ were taken for each montage. Based on previous physiological and morphological studies showing that the outer and middle third of the IPL may correspond to regions of input from OFF and ON cone bipolar terminals, respectively (Nelson et al., 1978; Peichl and Wässle, 1981; Amthor et al., 1989), the first five images were classified into the sublamina a (OFF layer), whereas the sixth to the 11 th images were sublamina $b$ (ON layer). Occasionally, a few cone bipolar cell dyads found in the inner third of the IPL (populated primarily by ON rod bipolar cell dyads) also were considered as ON layer. Cone bipolar cell dyad profiles were accepted for analysis when (1) they contained retrogradely transported CTB signal, (2) related ribbon synapses exhibited well defined membranes, clefts, and postsynaptic densities, and (3) CTB-positive dendrites contained at least two gold particles within the PSD or more than one gold particle along the extrasynaptic plasma membrane. The total cone bipolar cell dyads accepted for analysis for NMDARs were $68,56,102$, and 53 for NR1C2, NR2B, NR1C2', and NR2A, respectively, whereas those for MAGUKs were 56, 14, 77, and 75 for SAP102, SAP97, PSD-95, and PSD-93, respec-
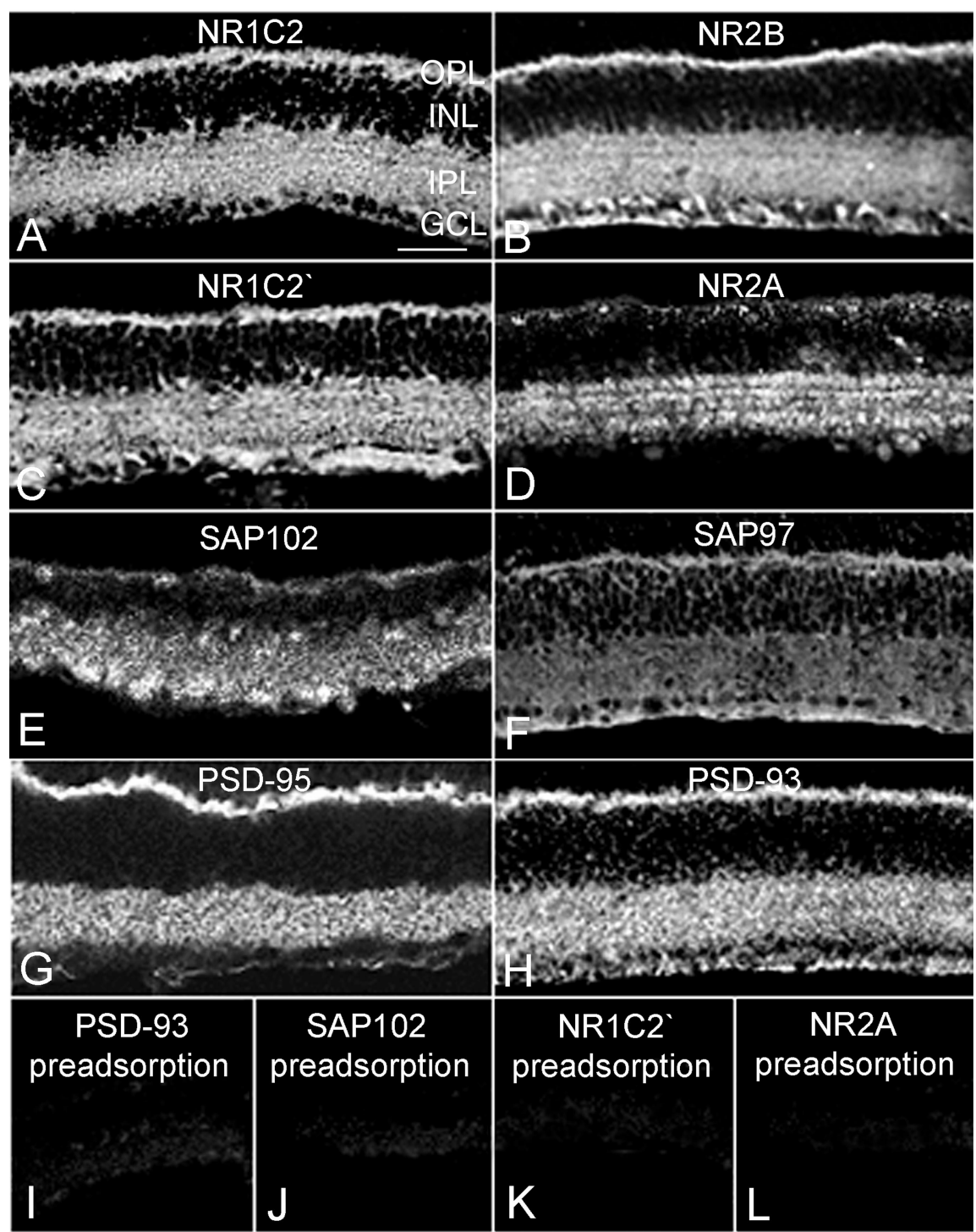

Figure 1. Light microscopy immunoreactivity (IR) for NMDAR subunits and MAGUK proteins in the rat retina. $A-D, N M D A R$ subunit IR is evident in the IPL, OPL, GCL, and INL. $\boldsymbol{E}-\boldsymbol{H}$, MAGUK protein IR is evident primarily in the IPL and OPL. I-L, Preadsorption with peptide antigen (e.g., for PSD-93, SAP102, NR1C2' , and NR2A) blocks primary antibody IR. $\boldsymbol{M}-\mathbf{N}$, IR of NR1C2 and NR2B on cryosections of rat cerebellum. $\mathbf{0}$, Double labeling of NR2A (01) and Calbindin D-28k (02) on the same cryosection of rat cerebellum. Scale bars: $50 \mu \mathrm{m}$ (in $\boldsymbol{A}$, corresponds to $\boldsymbol{A}-\boldsymbol{L}$; in $\mathbf{0 1}$, corresponds to $\boldsymbol{M}-\mathbf{0 2}$ ).

tively. To control for variability between animals, labeling of each antibody was examined in tissue from three different rats, and the results were pooled.

The mean length of the PSD and the extrasynaptic plasma membrane of individual RGC dendrites was measured to be $180 \pm 9 \mathrm{~nm}(n=94)$ and $1592 \pm 96 \mathrm{~nm}(n=51)$ (Zhang and Diamond, 2006), respectively, using NIH ImageJ software. Given an average thickness of 7-9 $\mathrm{nm}$ for the plasma membrane (Peters et al., 1991) and our criteria for transversely cut ribbon synapses, we counted gold particles within the $10 \mathrm{~nm}$ of the membrane as membrane-associated (Nusser et al., 1995). Particle density was calculated as the number of gold particles per linear micrometer. The 
lateral location of each gold particle was measured as the distance between the center of the particle and the middle of the PSD (for synaptic gold), or the edge of the PSD (for extrasynaptic gold).

Slice preparation and solutions for electrophysiology. Retinal slices were prepared from juvenile (P17-P21) Sprague Dawley rats according to National Institute of Neurological Disorders and Stroke Animal Care and Use guidelines, as described previously (Chen and Diamond, 2002). Following enucleation and hemisection of the eye, the retina was removed from the eyecup and submerged in $2 \%$ low-melting point agarose (type VII, Sigma), then cut into $200 \mu \mathrm{m}$ slices on a vibratome (Ted Pella). Dissection, slicing, and storage occurred in artificial CSF (ACSF) containing the following (in mM): 119 $\mathrm{NaCl}, 2.5 \mathrm{KCl}, 1.3 \mathrm{MgCl}_{2}, 2.5 \mathrm{CaCl}_{2}, 26.2$ $\mathrm{NaHCO}_{3}, 1 \mathrm{NaH}_{2} \mathrm{PO}_{4}, 20$ glucose, $2 \mathrm{Na}$ pyruvate, and $4 \mathrm{Na}$ lactate, bubbled with $95 \%$ $\mathrm{O}_{2}-5 \% \mathrm{CO}_{2}$. The recording chamber was superfused continuously with ACSF supplemented with picrotoxin $(100 \mu \mathrm{M})$, TPMPA (50 $\mu \mathrm{M})$, strychnine $(10 \mu \mathrm{M})$, and TTX $(1 \mu \mathrm{M})$ to block $\mathrm{GABA}_{\mathrm{A}}, \mathrm{GABA}_{\mathrm{C}}$, and glycine receptors, respectively, and the NMDAR coagonist D-serine $(100 \mu \mathrm{M}) . \mathrm{MgCl}_{2}$ was replaced with equimolar $\mathrm{CaCl}_{2}$. The internal patch solution contained (mM): 120 Cs methanesulfonate, 10 EGTA, 20 HEPES, 0.05 Alex Fluor 488, 2 MgATP, and 0.2 NaGTP. Solutions were adjusted to pH 7.4 with $\mathrm{NaOH}$ or $\mathrm{CsOH}$, and 290-300 mOsm with sucrose. All experiments were performed at room temperature $\left(21-23^{\circ} \mathrm{C}\right)$. Reagents were obtained from Sigma, except for TBOA, Ro 25-6981 (Tocris Cookson), TTX (Alomone Labs), and Alexa Fluor 488 (Invitrogen).

Electrophysiology. Voltage-clamp recordings were made from RGCs with whole-cell patch electrodes (4-5 M $\Omega$, \#0010 glass, World Precision Instruments) and an Axopatch 1D amplifier (Molecular Devices) in voltage-clamp mode. Access resistance (10-30 M $\Omega$ ) was monitored continuously and not compensated. Dialysis of the cytosol with Alexa Fluor 488 allowed the RGCs to be visualized with epifluorescence and identified as $\mathrm{ON}$ or OFF based on dendritic ramification in the inner or outer IPL, respectively. Bistratified ONOFF cells were not analyzed. Data acquisition and analysis were performed with custom macros written in IgorPro (WaveMetrics). Data were filtered at $5 \mathrm{kHz}$ and sampled at $10 \mathrm{kHz}$. mEPSCs were detected in IgorPro with an optimally scaled template algorithm (Clements and Bekkers, 1997).

Statistical analysis was performed using Stata 8, StatsDirect, IgorPro, and Excel (Microsoft) software. Two-tailed $t$ tests and KolmogorovSmirnov tests were used to compare means and distributions, respectively, and significance was concluded when $p<0.05$. Unless indicated otherwise, values are reported as mean \pm SEM.

\section{Results}

NR1C2 and NR2B subunits are located perisynaptically

Our previous work identified NMDARs at RGC synapses using a mixture of antibodies to the NR1C2 and NR2B subunits. Here, we first examined these antibodies separately, first at the LM level. Immunofluorescence for both antibodies was evident in the IPL and
NR1C2
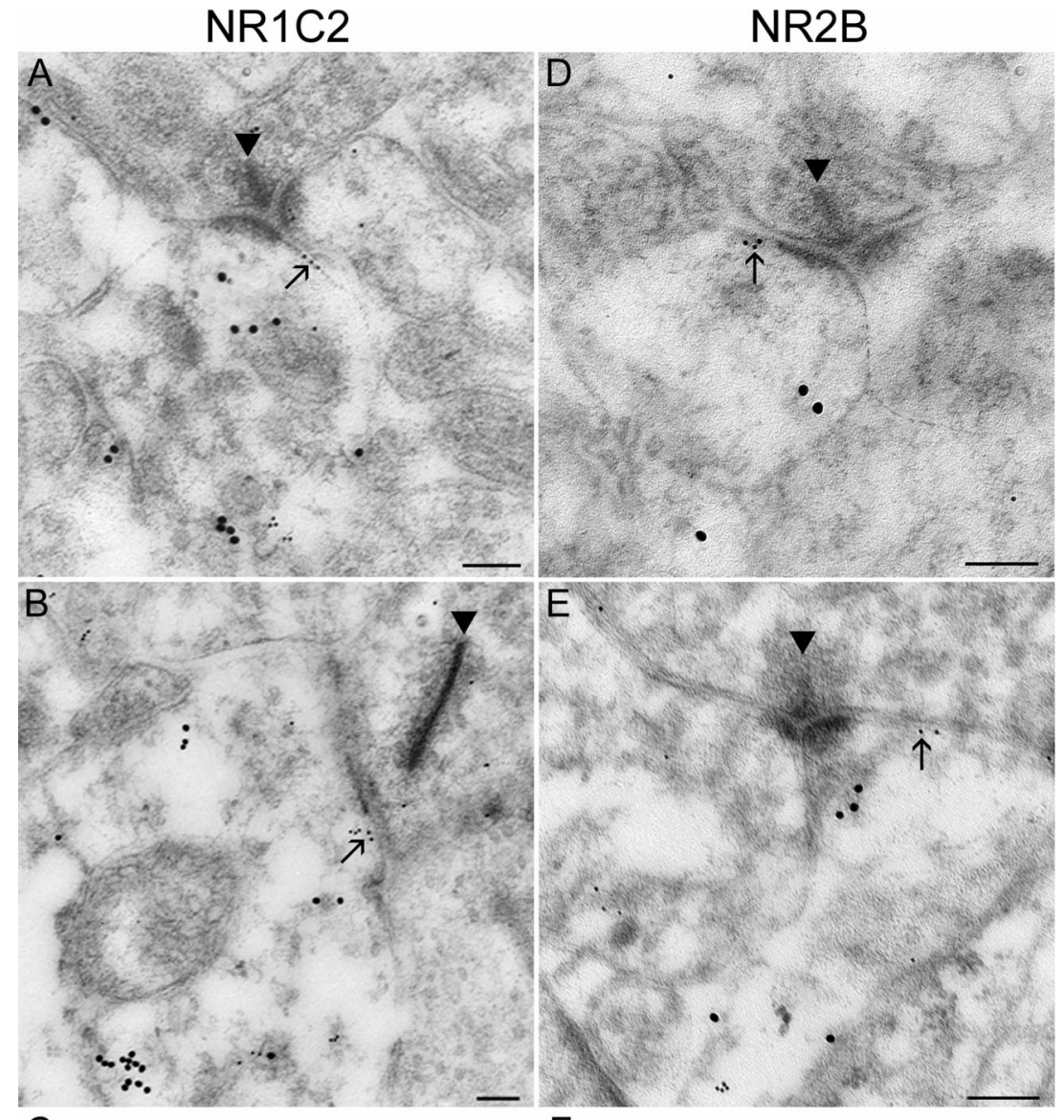

C

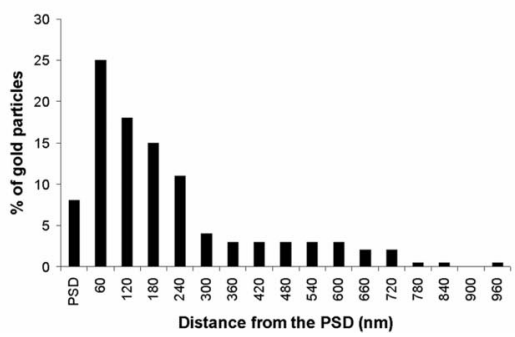

$\mathrm{F}$

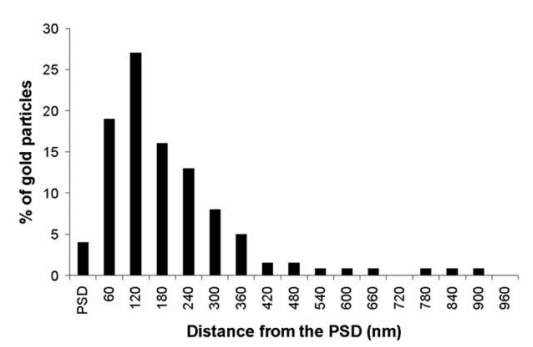

Figure 2. Immunogold labeling shows perisynaptic localization of NR1C2 and NR2B at cone bipolar cell dyads. $A, B$, Labeling for NR1C2 (small particles, arrow) and CTB (large particles). Presynaptic ribbons indicated by arrowheads. C, Histogram showing the tangential distribution of gold labeling NR1C2 at synapses in 0 N and OFF sublaminae ( $n=68$ profiles). D, E, Labeling for NR2B show profiles in OFF sublaminae. $F$, Histogram showing the tangential distribution of gold labeling NR2B in ON and OFF sublaminae ( $n=56$ profiles). No significant difference was observed between the distributions in $\boldsymbol{C}$ and $\boldsymbol{F}$ (Kolmogorov-Smirnov test, $p=0.19)$. The perisynaptic region was divided into $60 \mathrm{~nm}$ bins. Scale bars: $0.1 \mu \mathrm{m}$.

outer plexiform layer (OPL), in addition to somatic labeling in the ganglion cell layer (GCL) and inner nuclear layer (INL) (Fig. 1 $A, B$ ), similar to previous reports in rat retina (Fletcher et al., 2000; Kalloniatis et al., 2004; Zhang and Diamond, 2006). These antibodies were then applied to tissue in which RGCs had been retrogradely labeled with CTB and then processed for immunogold EM. To determine the exact localization of NR1C2 and NR2B subunits in the postsynaptic and extrasynaptic membranes of RGC dendrites, the tangential distribution of gold particles within the PSD and along the extrasynaptic membrane was measured. The large majority of particles labeling either NR1C2 (92\%) or NR2B (96\%) was located outside the PSD, distributed primarily along the extrasynaptic plasma membrane and positioned mostly on its intracellular face (Fig. 2). These results are consistent with our previous report (Zhang and Dia- 
mond, 2006) in which these two antibodies were applied together. The distribution pattern of NR1C2 and NR2B gold particles at positive synapses was not significantly different (Fig. $2 C, F)(p=0.19)$, with the peak particle density for both subunits occurring $180 \mathrm{~nm}$ from the edge of the PSD (see Fig. $4 A$ ). The few NR1C2 and NR2B particles detected within the PSD were located at the lateral edges (see Fig. 4B) (also see Zhang and Diamond, 2006). For these and all the antibodies in this study (except CTB), $>95 \%$ of the labeled dendritic profiles had gold either in the PSD or in the extrasynaptic membrane, but not both. Therefore, we also calculated the incidence of perisynaptic labeling by classifying each individual profile as exhibiting either synaptic or extrasynaptic immunoreactivity. This approach yielded perisynaptic percentages for NR1C2 (90\%) and NR2B (95\%) (see Fig. 5A) that were similar to those obtained by counting individual particles. Together, these results indicate that NR1C2 and NR2B subunits are distributed almost exclusively in the perisynaptic membrane.

\section{NR1C2' and NR2A subunits are} localized primarily within the PSD

We next examined the subsynaptic distribution of NR1C2' and NR2A subunits, first at the LM level. Strong, punctate labeling was present in the IPL and OPL for both subunits (although the NR2A signal was somewhat weaker in the OPL), and somatic labeling was evident in the GCL and INL (Fig. 1C,D), consistent with previous work in rat (Hartveit et al., 1994; Fletcher et al., 2000; Gründer et al., 2000; Kalloniatis et al., 2004). At the EM level, immunogold for both antibodies was localized primarily to the PSD (Figs. 3, 4A), in striking contrast to the data for NR1C2 and NR2B (Fig. 2). The distributions of NR1C2' (81\% in the PSD) (Fig. 3C) and NR2A ( $83 \%$ in the PSD) (Fig. $3 F$ ) were indistinguishable $(p=1)$. Within the PSD, gold particles for NR1C2' were distributed evenly along the postsynaptic membrane, whereas those for NR2A were more concentrated at the center of the PSD (Fig. $4 B$ ).

\section{NR2B, but not NR1C2, is preferentially expressed at ON synapses}

RGCs respond to the onset and/or the offset of light stimulation (e.g., Werblin and Dowling, 1969), depending on whether they receive synaptic input from $\mathrm{ON}$ and/or OFF bipolar cells in the middle and outer thirds of the IPL, respectively (Nelson et al., 1978; Peichl and Wässle, 1981; Amthor et al., 1989). To compare the subsynaptic distribution of NMDAR subunits at ON and OFF synapses, we analyzed separately synaptic profiles located in the $\mathrm{ON}$ and OFF sublaminae (see Materials and Methods). Although both synaptic layers were surveyed approximately equally, NR2B-positive profiles were twice as prevalent in the ON layer
NR1C2
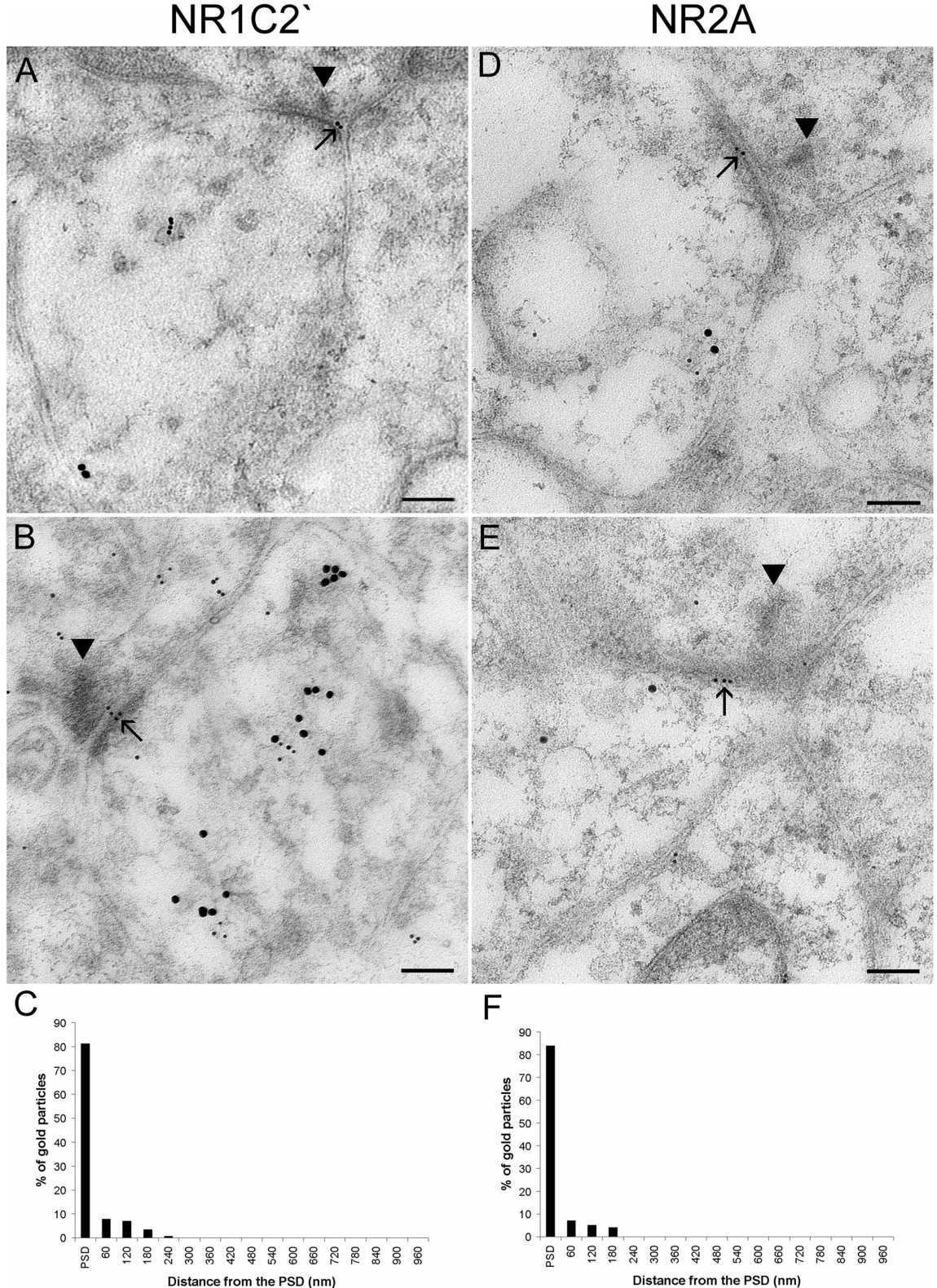

$\mathrm{F}$

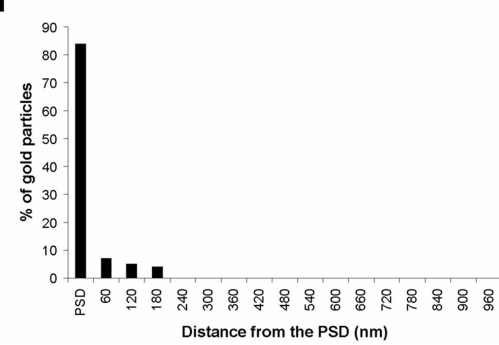

Figure 3. Immunogold labeling shows synaptic localization of NR1C2' and NR2A at cone bipolar cell dyads. $\boldsymbol{A}, \boldsymbol{B}$, Labeling for NR1C2' (small particles, arrow) and CTB (large particles). Presynaptic ribbons indicated by arrowheads. $C$, Histogram showing the tangential distribution of gold labeling NR1C2' in ON and OFF sublaminae ( $n=102$ profiles). $\boldsymbol{D}, \boldsymbol{E}$, Labeling for NR2A (small profiles in OFF sublaminae. $\boldsymbol{F}$, Histogram showing the tangential distribution of gold labeling NR2A in ON and OFF sublaminae $n=53$ profiles). No significant difference was observed between the distributions in $\boldsymbol{C}$ and $\boldsymbol{F}$ (Kolmogorov-Smirnov test, $p=$ 1.00). The perisynaptic region was divided into $60 \mathrm{~nm}$ bins. Scale bars: $0.1 \mu \mathrm{m}$.

compared with the OFF layer (64\% vs $36 \%$ ), in contrast to NR1C2, which was distributed evenly between the two layers (50\% vs $50 \%$ ) (Fig. $5 A$ ). This last result likely explains why no ON/OFF asymmetry was detected with an NR1C2/NR2B antibody mixture (Zhang and Diamond, 2006). There was no difference between the average density of gold particles at positive synapses in the ON and OFF layers for either NR1C2 or NR2B (Fig. $5 B, C$ ).

\section{$\mathrm{NR} 2 \mathrm{~A}$ and NR1C2' are preferentially expressed at OFF synapses}

In contrast to NR2B, which was detected primarily in the $\mathrm{ON}$ layer of the IPL, $62 \%$ and $66 \%$ of NR1C2' - and NR2A-positive 

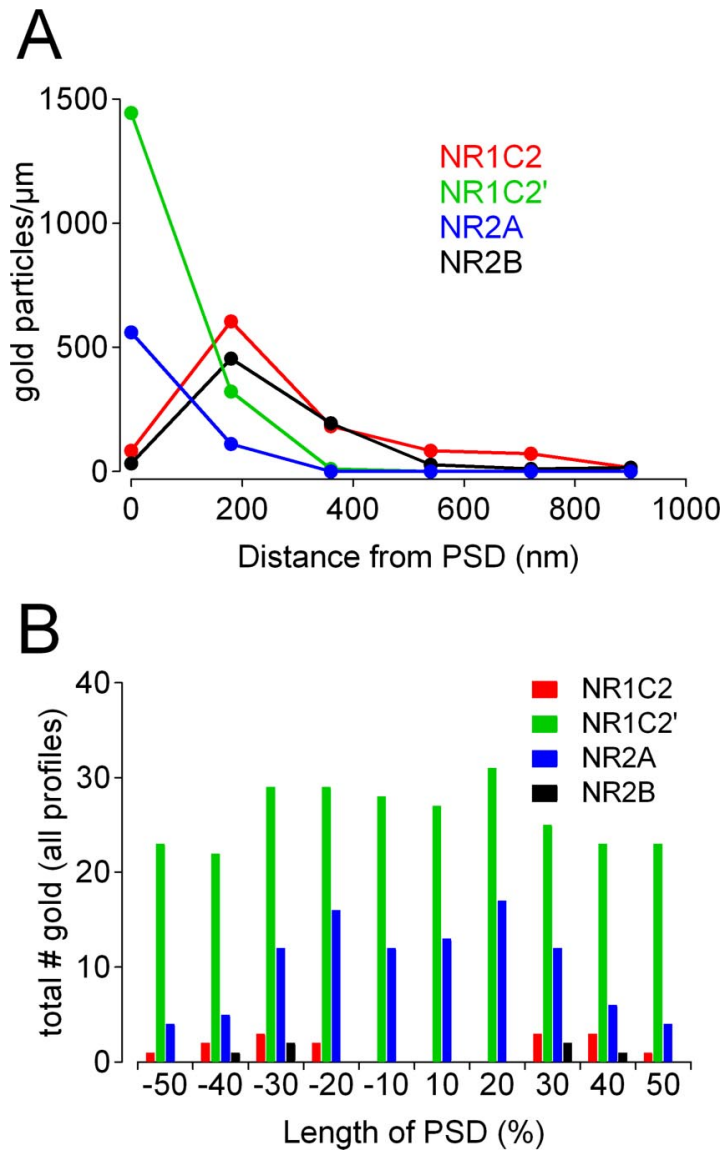

Figure 4. Comparison of NMDAR subunit localization in RGC dendrites. A, Histogram showing labeling density of immunogold particles for NR1C2 ( $n=68$ profiles), NR1C2' $(n=102$ profiles), NR2A ( $n=53$ profiles), and NR2B ( $n=56$ profiles). The perisynaptic region was divided into $180 \mathrm{~nm}$ bins from the edge of the PSD. $\boldsymbol{B}$, Histogram showing the tangential distribution of the total number of immunogold particles for NR1C2 ( $n=7$ profiles), NR1C2' ( $n=80$ profiles), NR2A ( $n=44$ profiles), and NR2B ( $n=3$ profiles) at all profiles with labeling within the PSD.

dendritic profiles, respectively, were detected in the OFF layer (Fig. 5A). The labeling density for NR1C2' and NR2A gold particles at positive profiles was comparable in the $\mathrm{ON}$ and OFF layers, although synaptic NR1C2' density was significantly higher in the OFF layer (Fig. $5 B, C$ ). Together, the data presented so far indicate that different NMDAR subunits exhibit distinct synaptic and perisynaptic expression patterns and preferences for particular functional layers of the inner retina. Moreover, they show a strong correlation in expression between particular NR1 splice variants and NR2 subunits (i.e., NR1C2-NR2B and NR1C2'-NR2A).

It should be noted that, in many cases, gold particles were observed in the intracellular compartment of presynaptic and postsynaptic profiles (Figs. 2, 3). This could represent nonspecific staining, or NMDARs in intracellular organelles, perhaps in the process of being trafficked to or from the plasma membrane. The very low levels of IR in mitochondrial membranes (Fig. $5 D$ ) suggest that nonspecific staining is minimal under these conditions.

\section{Contrasting subsynaptic localization of different}

MAGUK proteins

MAGUKs are thought to tether NMDAR subunits to specific locations in the plasma membrane, but it remains unclear
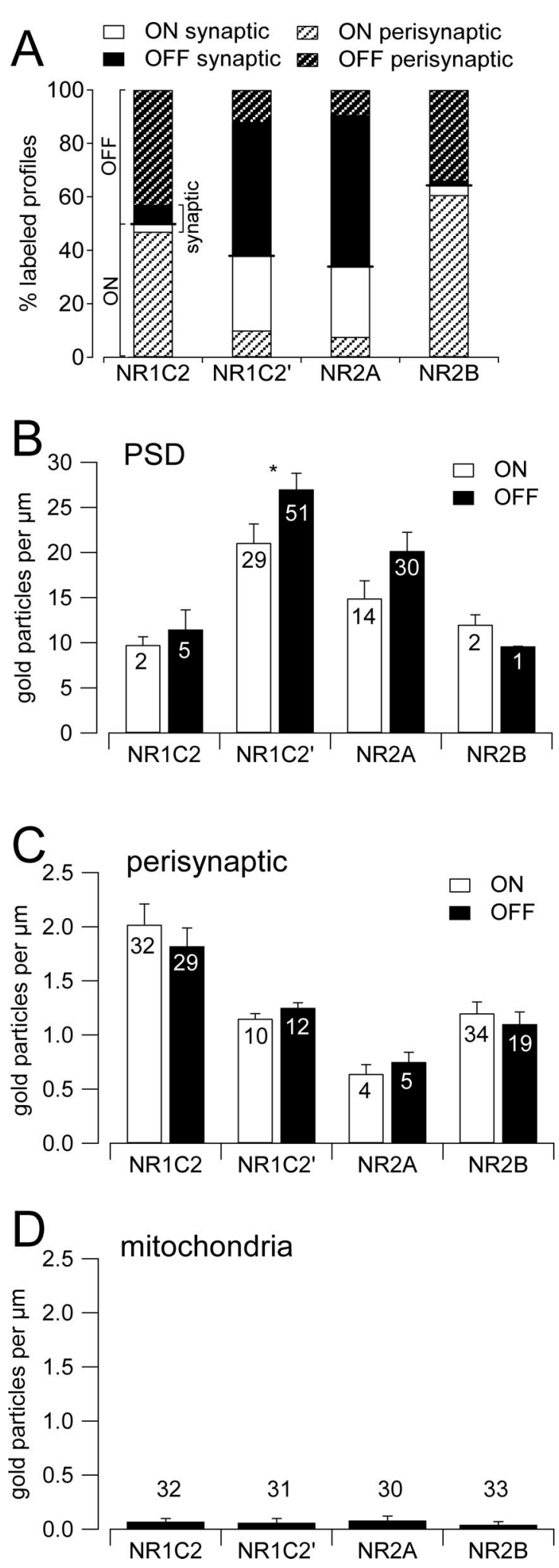

Figure 5. Quantitative comparison of NMDAR subunits in RGC dendrites in the ON and OFF sublaminae. $A$, Cumulative bar graph showing the relative fraction of IR-positive dendritic profiles in the ON (light) and OFF (dark) sublaminae, within the PSD (solid) and in perisynaptic membranes (hatched). In each bar, the thick black line marks the relative proportion of ON and OFF profiles. The ratio of solid and hatched regions (light or dark) indicates the relative amounts of synaptic and perisynaptic expression. $\boldsymbol{B}$, Comparison of particle density within the IR-positivePSDs in the ON (open) and OFF (solid) sublaminae. C, Comparison of particle density in IR-positive perisynapticmembranes in the ON (open) and OFF (solid) sublaminae. $\boldsymbol{D}$, Particle density in mitochondrial membrane indicates relatively little nonspecific IR (ON and OFF sublaminae combined). $n$ values indicate the number of profiles analyzed. 
SAP102

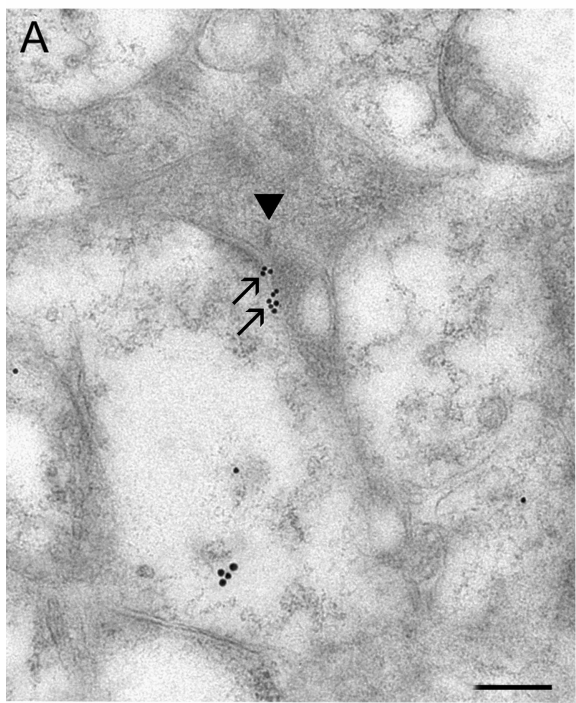

B

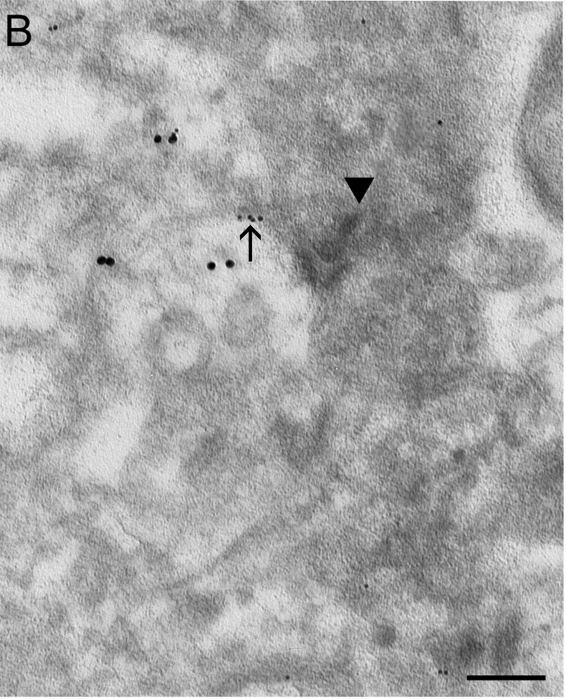

C

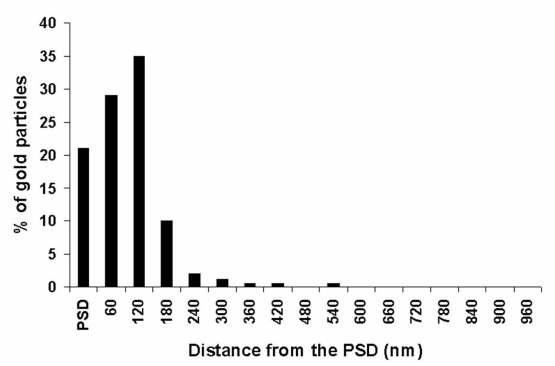

PSD-95
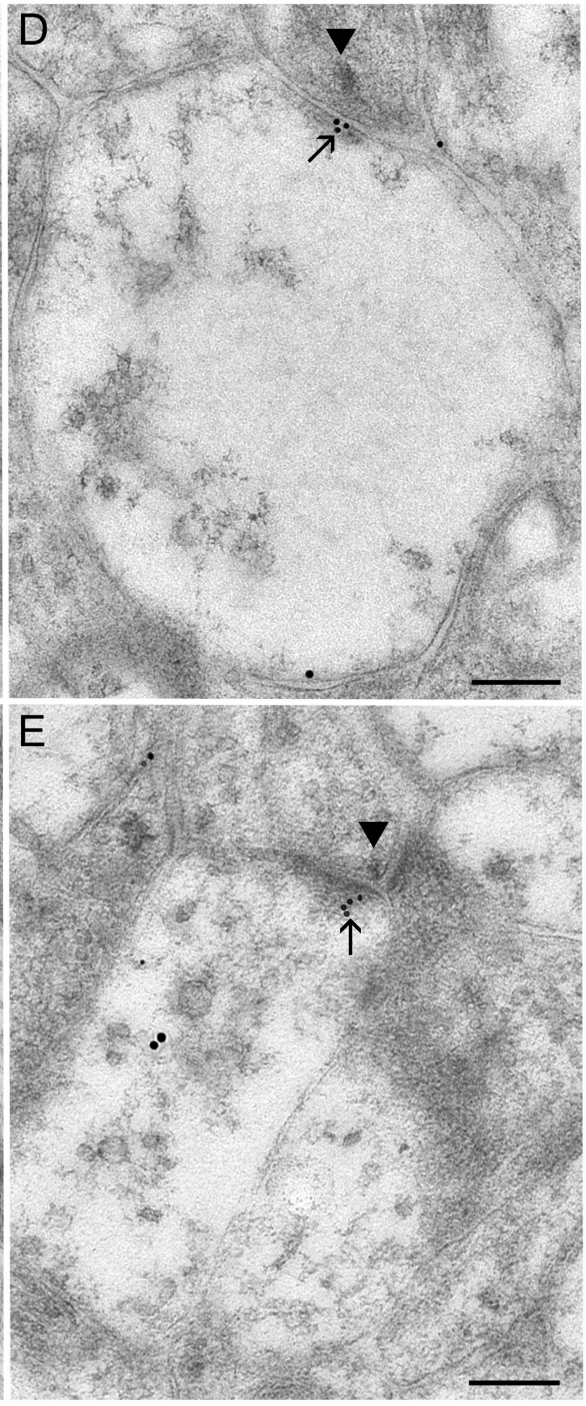

F

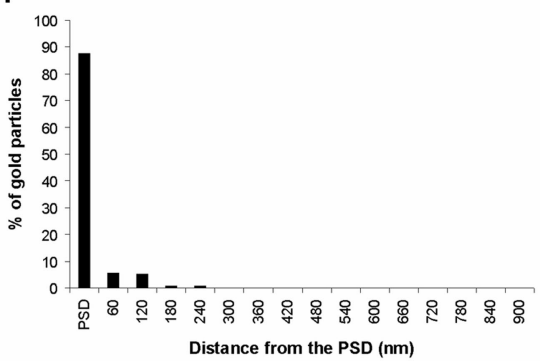

PSD-93
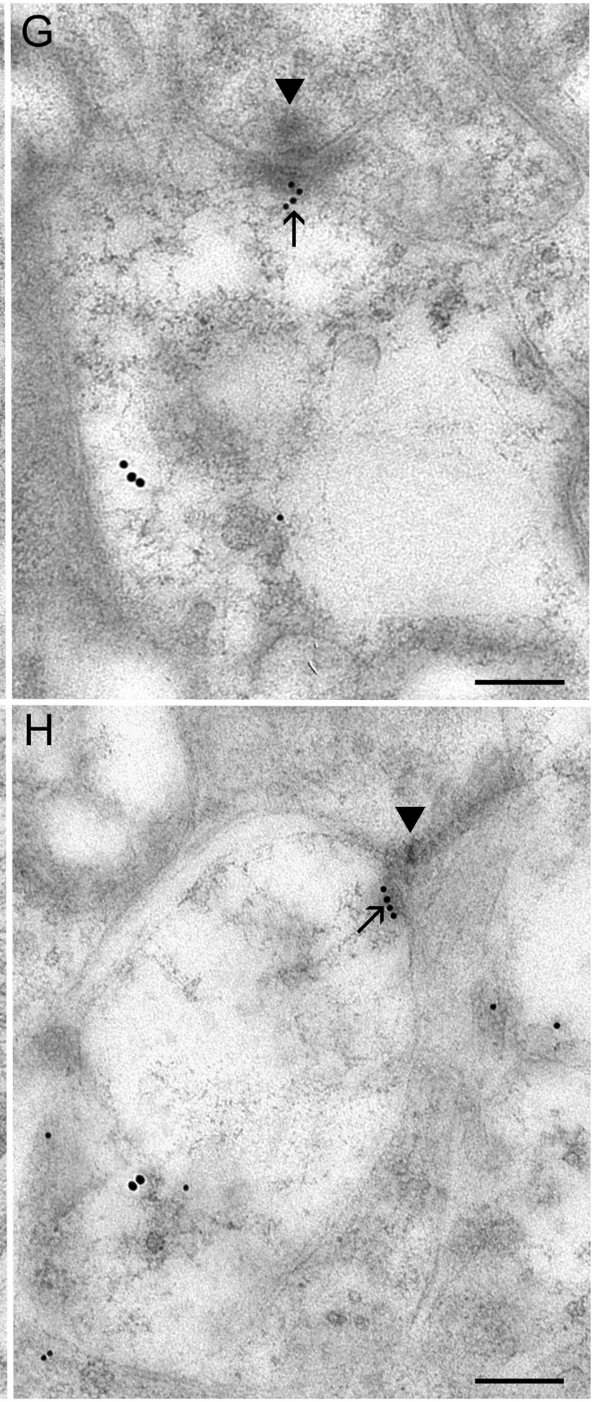

I

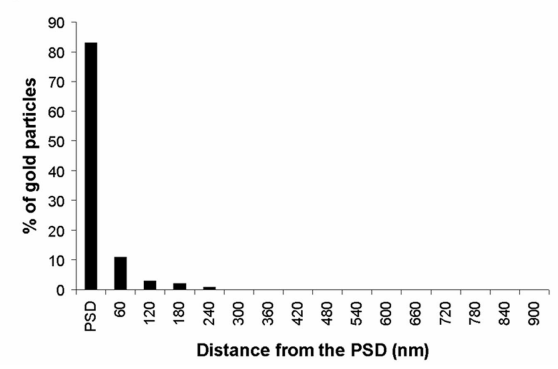

Figure 6. Immunogold labeling shows subsynaptic localization of MAGUK proteins. $A, B$, Labeling for SAP102 (small particles, arrow) and (TB (large particles). Presynaptic ribbons indicated by arrowheads. C, Histogram showing the tangential distribution of gold labeling SAP102 ( $n=56$ profiles). D, E, Labeling for PSD-95 (small particles, arrow) and (TB (large particles). $\boldsymbol{F}$, Histogram showing the tangential distribution of gold labeling PSD-95 ( $n=77$ profiles). $\mathbf{G}, \boldsymbol{H}$, Labeling for PSD-93 (small particles, arrow) and (TB (large particles). Micrographs in $\boldsymbol{A}, \mathbf{D}$, and $\mathbf{G}$ show profiles in ON sublaminae; micrographs in $\boldsymbol{B}, \boldsymbol{E}$, and $\boldsymbol{H}$ show profiles in OFF sublaminae. $\boldsymbol{I}$, Histogram showing the tangential distribution of gold labeling PSD-93 ( $n=75$ profiles). No significant difference was observed between the distributions in $\boldsymbol{F}$ and $\boldsymbol{I}$ (Kolmogorov-Smirnov test, $p=1.00$ ). The perisynaptic region was divided into $60 \mathrm{~nm}$ bins. Scale bars: $0.1 \mu \mathrm{m}$.

whether particular NMDAR subunits associate specifically with particular MAGUKs. To address this issue in RGCs, we examined the expression of MAGUKs in the rat retina, first at the LM level. Intense immunofluorescence in the IPL was observed for SAP102, PSD-95, and PSD-93, similar to previous reports (Koulen et al., 1998a,b; Koulen, 1999), with SAP97 giving a weaker signal (Fig. $1 E-H$ ). At the EM level, SAP102 expression was similar to that of NR1C2 and NR2B, with 79\% of the plasma membrane-associated gold particles outside the PSD (Fig. 6A-C) and a peak density $180 \mathrm{~nm}$ from the edge of the PSD (Fig. 7A). In contrast, the large majority of PSD-95 (88\%) (Figs. 6D-F, 7A) and PSD-93 (83\%) (Figs. 6G-I, 7A) immunogold was contained 

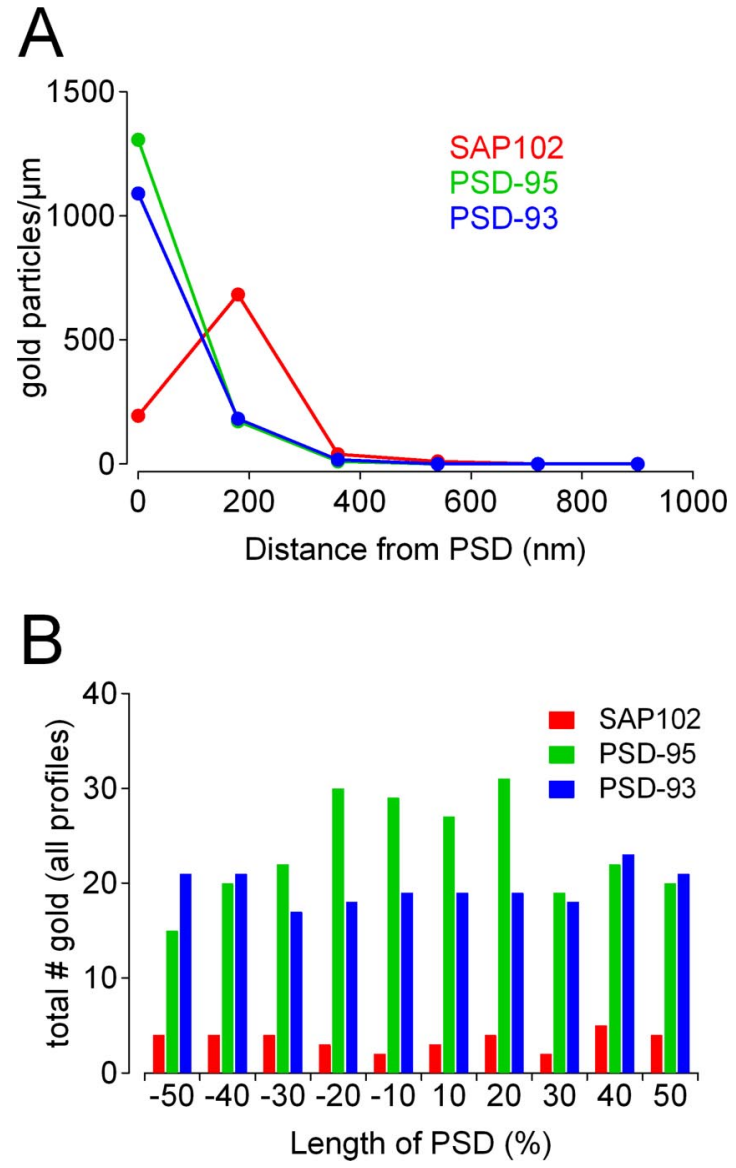

Figure 7. Comparison of MAGUK protein localization in RGC dendrites. $A$, Histogram showing labeling density of immunogold particles for SAP102 ( $n=56$ profiles), PSD-95 ( $n=77$ profiles), and PSD-93 ( $n=75$ profiles). The perisynaptic region was divided into $180 \mathrm{~nm}$ bins from the edge of the PSD. $\boldsymbol{B}$, Histogram showing the tangential distribution of the total number of immunogold particles for SAP102 ( $n=12$ profiles), PSD-95 ( $n=69$ profiles), and PSD-93 ( $n=61$ profiles) at all profiles with labeling within the PSD.

within the PSD, similar to NR1C2' and NR2A. Within the synapse, labeling for all three proteins was relatively even across the width of the PSD (Fig. 7B). The antibody to SAP97 labeled only 14 RGC profiles at the EM level and was not analyzed quantitatively.

Similar to NR1C2, SAP102 immunogold was evenly distributed across the ON and OFF layers (54\% vs 46\%) (Fig. 8A). Labeling for PSD-95 and PSD-93, however, was more prevalent in the OFF layer (67\% and $72 \%$, respectively, in the OFF layer) (Fig. $8 A$ ). As observed with NMDAR subunits, the major ON versus OFF differences were with respect to the frequency of labeled synapses, not the labeling density within positive synapses (Fig. $8 B, C$ ). Labeling for all three MAGUKs was relatively low in mitochondrial membranes (Fig. $8 D$ ), suggesting that nonspecific staining was minimal.

\section{Distinct NMDAR subtype contributions to sEPSCs at ON and OFF synapses}

The results presented thus far delineate a complex pattern of NMDAR expression in the IPL. NMDARs are located mostly perisynaptically at ON synapses and primarily within the PSD at OFF synapses. Perisynaptic NMDARs are not activated by glutamate released during spontaneous synaptic events unless the spatial extent of transmitter diffusion is expanded by blocking glu-
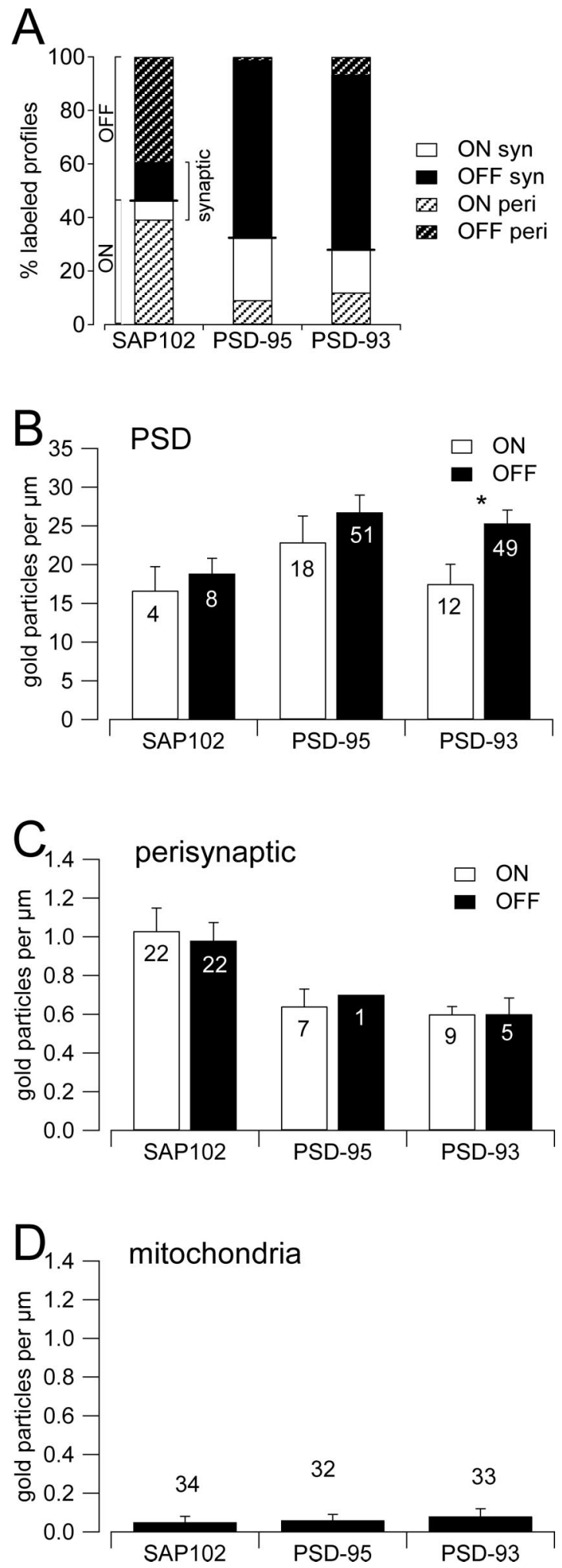

Figure 8. Quantitative comparison of MAGUK proteins in RGC dendrites in the ON and OFF sublaminae. $\boldsymbol{A}$, Cumulative bar graph showing the relative fraction of IR-positive dendritic profiles in the ON (light) and OFF (dark) sublaminae, within the PSD (syn; solid) and in perisynapticmembranes (peri; hatched). In each bar, the thick black line marks the relative proportion of ON and OFF profiles. The ratio of solid and hatched regions (light or dark) indicates the relative amounts of synaptic and perisynaptic expression. $\boldsymbol{B}$, Comparison of particle density within the IR-positivePSDs in the ON (open) and OFF (solid) sublaminae. C,Comparison of particle density in IR-positive perisynapticmembranes in the ON (open) and OFF (solid) sublaminae. D, Particle density in mitochondrial membrane indicates relatively little nonspecific IR(ON and OFF sublaminae combined). $n$ values indicate the number of profiles analyzed. 


\section{A ONRGC B}

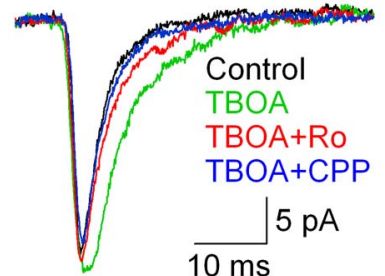

C OFF RGC

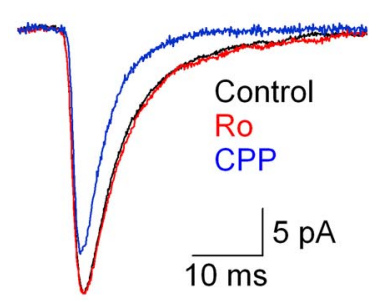

\section{E OFFRGC}

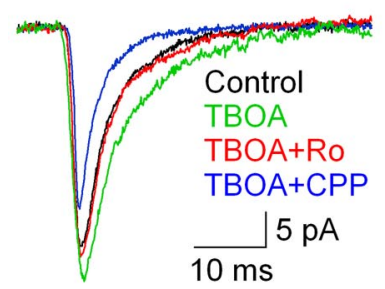

G OFF RGC

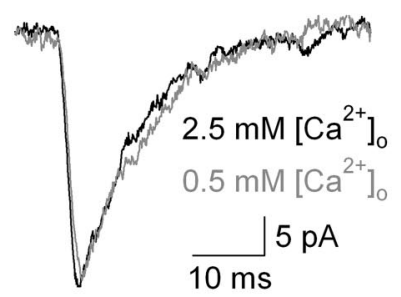

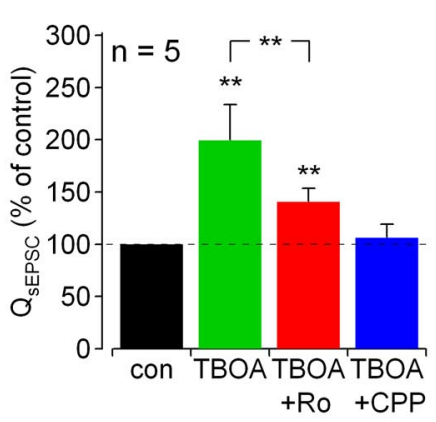
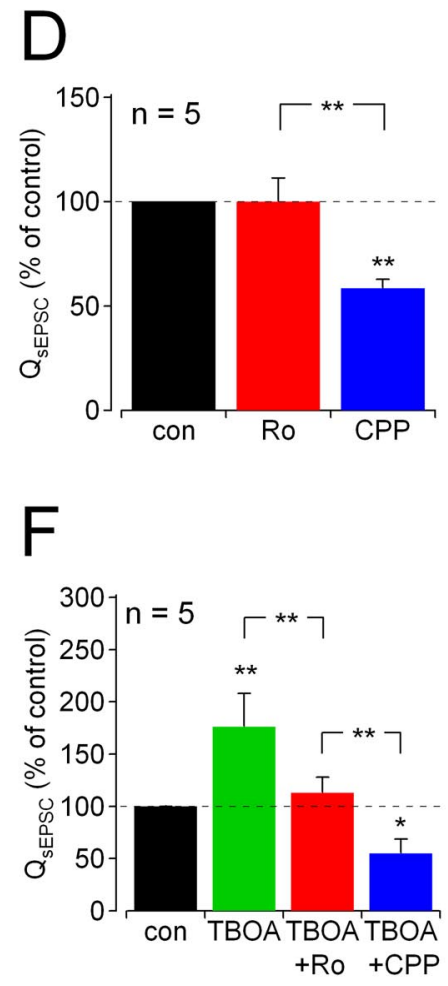

$\mathrm{H}$

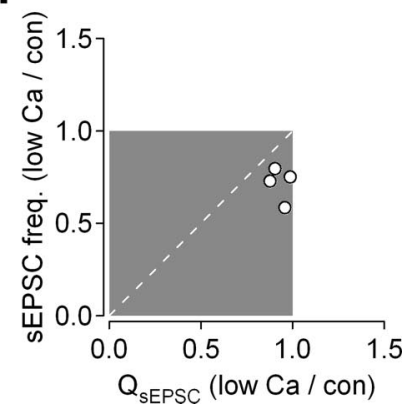

Figure 9. Distinct NMDAR subtype contributions to $S E P S C S$ at $0 \mathrm{~N}$ and OFF synapses. A, Average sEPSCs recorded form a morphologically identified ON RGC ( $V_{\text {hold }}=-80 \mathrm{mV}, 1 \mu \mathrm{m}$ TTX, $100 \mu \mathrm{M}$ D-serine, $0\left[\mathrm{Mg}^{2+}\right]_{0}$, inhibition blocked). Reducing glutamate uptake with the transporter antagonist TBOA (10 $\mu \mathrm{m}$, green, 95 events averaged) conferred a slow component onto the sEPSC waveform compared with control (black, 135 events). This TBOA-induced component was reduced by the NR2B NMDAR-specific antagonist Ro 25-6981 (Ro, $1 \mu \mathrm{m}$, red, 106 events) and abolished completely by the pan-NMDAR antagonist CPP (10 $\mu \mathrm{M}$, blue, 110 events). $\boldsymbol{B}$, Summarized effects of TBOA, Ro 25-6981, and (PP in five ON RGCS. C, Average sEPSCs recorded from an identified OFF RGC in the same control conditions as above (black, 425 events). In the absence of TBOA, Ro 25-6981 (red, 202 events) had no effect on the sEPSC waveform but CPP blocked a slow component (blue, 88 events), indicating the presence of synaptic NMDARs that lack NR2B subunits. D, Summarized effects of Ro 25-6981 and CPP in five OFF RGCS. $E$, Average SEPSCs recorded from an identified OFF RGC in the same control conditions as above (black, 133 tamate uptake (Chen and Diamond, 2002). Recent physiological data in mouse retina, showing that sEPSCs at OFF synapses exhibit an NMDAR component while sEPSCs at ON synapses do not unless release is enhanced by blocking presynaptic inhibition (Sagdullaev et al., 2006), are consistent with the anatomical ONOFF asymmetry described here. Our findings also indicate that NR2B NMDARs are more prevalent at ON synapses, while NR2A NMDARs are more prevalent at OFF synapses. To examine the physiological consequences of this segregation, sEPSCs were recorded from morphologically identified ON and OFF RGCs (see Materials and Methods). $\mathrm{Mg}^{2+}$ was removed from the extracellular solution to permit detection of NMDARs at a holding potential of $-80 \mathrm{mV}$, and inhibition mediated by glycine, $\mathrm{GABA}_{\mathrm{A}}$, and $\mathrm{GABA}_{\mathrm{C}}$ receptors was blocked (see Materials and Methods). In ON RGCs, sEPSC decay was slowed by addition of the glutamate transporter antagonist TBOA $(10 \mu \mathrm{M})($ Fig. $9 A)$, resulting in a $99 \pm 34 \%(n=5)$ increase in the charge transfer of the average sEPSC $\left(Q_{\text {sEPSC }}\right)$ (Fig. 9B). This enhancement was reduced $59 \pm$ $6 \%$ by the NR2B NMDAR-specific antagonist Ro 25-6981 (1 $\mu \mathrm{M})$ and eliminated completely by CPP $(10 \mu \mathrm{M})$, which blocks all NMDAR subtypes (Fig. 9A,B). $Q_{\text {sEPSC }}$ in the presence of CPP was indistinguishable from that in control (106 $\pm 13 \%$ of control, $n=5, p=0.45$ ), indicating negligible NMDAR activation at ON synapses during sEPSCs in control conditions, even when presynaptic $\mathrm{GABA}_{\mathrm{C}} \mathrm{Rs}$ were blocked (Chen and Diamond, 2002) (but see Sagdullaev et al., 2006). These results are consistent with a predominantly perisynaptic localization of Ro 25-6981sensitive NR2B NMDARs at ON synapses (Figs. 2, 4, 5). In contrast, $Q_{\text {sEPSC }}$ in OFF RGCs was unaffected by Ro 25-6981 (100 \pm $12 \%$ of control, $n=5, p=0.95$ ) but was reduced significantly by CPP (to $58 \pm 4 \%$ of control, $n=5, p=0.002$ ), even with glutamate uptake intact, consistent with NR2B-lacking NMDARs targeted to the PSD. To determine whether perisynaptic NMDARs also are present at some OFF synapses, as suggested by our anatomical data (Fig. $5 \mathrm{~A}$ ), we also examined the effects of TBOA on OFF sEPSCs. TBOA $(10 \mu \mathrm{M})$ slowed the decay of OFF sEPSCs and caused an increase in the average $Q_{\text {sEPSC }}$ (to $176 \pm 32 \%$ of control, $n=5, p=0.003$ ) (Fig. $9 E, F$ ). This enhancement was reduced almost completely by Ro $25-6981$ ( $1 \mu \mathrm{M}$; to $113 \pm 15 \%$ of control, $n=5, p=0.11$ vs control) (Fig. $9 E, F)$, suggesting that blocking transporters permits activation of perisynaptic NR2B NMDARs at OFF synapses, as at ON synapses. An Ro 25-6981insensitive, presumably non-NR2B NMDAR component was blocked by subsequent application of CPP (to $55 \pm 14 \%$ of control, $n=5, p=0.015$ vs control) (Fig. 9E, $F$ ).

Recent reports in mouse RGCs suggest that release probability is regulated differently at $\mathrm{ON}$ and OFF synapses and that spontaneous, multiquantal release can occur when presynaptic inhibition is blocked (Sagdullaev et al., 2006). It is possible, therefore, that the sEPSCs we recorded from OFF RGCs exhibited an NMDAR component because multiple vesicles were released during each sEPSC, enabling the activation of perisynaptic NMDARs. If this were true, $Q_{\text {sEPSC }}$ at OFF synapses should vary with changes in release probability and decrease if $\left[\mathrm{Ca}^{2+}\right]_{0}$ were

$\leftarrow$

events). Addition of TBOA enhanced the sEPSC waveform (green, 110 events), revealing a component that was eliminated by Ro 25-6981 (red, 120 events). CPP reduced the sEPSC waveform further (blue, 100 events). $F$, Summarized effects of TBOA, Ro 25-6981, and CPP in five OFF RGCS. $G$, Average sEPSCs recorded from an identified OFF RGC in the presence of TBOA (with inhibition blocked), in control (2.5 mM) $\left[\mathrm{Ca}^{2+}\right]_{0}$ (black, 89 events) or low $(0.5 \mathrm{~mm})\left[\mathrm{Ca}^{2+}\right]_{0}$ (gray, 59 events). $\boldsymbol{H}$, Effects of changing $\left[\mathrm{Ca}^{2+}\right]_{0}$ on sEPSC frequency and charge transfer in four OFF RGCS con, Control. 
reduced. Contrary to this prediction, in the presence of TBOA and with inhibition blocked, lowering $\left[\mathrm{Ca}^{2+}\right]_{\mathrm{o}}$ to $0.5 \mathrm{mM}$ reduced sEPSC frequency (to $71 \pm 9 \%$ of control, $n=4, p=0.017$ ) but caused only a small reduction in $Q_{\text {sEPSC }}$ that did not reach significance ( $93 \pm 5 \%$ of control, $n=4, p=0.076$ ) (Fig. 9G,H). A small decrease in $Q_{\mathrm{sEPSC}}$ actually would be expected due to the $\mathrm{Ca}^{2+}$ permeability of NMDARs (see Schneggenburger et al., 1993). These results suggest that sEPSCs at OFF RGC synapses in rat are predominantly uniquantal and that the NMDAR component present in OFF sEPSCs under control conditions (Fig. 9C,D) reflects the presence of synaptic NMDARs.

\section{Discussion}

The results presented here demonstrate four novel asymmetries in the expression of NMDARs and scaffolding proteins at $\mathrm{ON}$ and OFF RGC synapses in rat retina. First, NR2A and NR2B subunits are expressed predominantly synaptically and perisynaptically, respectively. Second, NR2A and NR2B subunits are expressed primarily at OFF and ON RGC synapses, respectively. Third, NR2A subsynaptic expression corresponds closely with the labeling of the NR1C2' antibody that recognizes $\mathrm{NR}_{3,4}$ splice variants, whereas NR2B expression corresponds to labeling of the NR1C2 antibody that recognizes $N R 1_{1,2}$ splice variants. Fourth, expression of different NR2 subunits mirrors that of different PDZ scaffolding proteins: NR2A expression corresponds to expression of PSD-95 and PSD-93 at synapses, whereas NR2B corresponds with SAP102 in perisynaptic membranes. These anatomical data are complemented by physiological recordings of sEPSCs from ON and OFF RGCs that indicate distinct NR2 subtype expression and subsynaptic localization at ON and OFF synapses. These results suggest that NMDAR subunits are assembled in particular combinations that dictate subsynaptic localization, association with particular membrane scaffolding proteins and specific functional roles within the retinal circuitry.

\section{Distinct perisynaptic and synaptic localization of NR2B and NR2A subunits at RGC synapses}

Work from several groups indicates that NMDARs are expressed in extrasynaptic membranes (Stocca and Vicini S, 1998; Rumbaugh and Vicini, 1999; Tovar and Westbrook, 1999; Chen and Diamond, 2002; Clark and Cull-Candy, 2002; Scimemi et al., 2004). The evidence that extrasynaptic NMDARs are particularly enriched in specific subunit combinations is more controversial. Physiological results from hippocampal and superior collicular neurons are consistent with the notion that NR2B-containing receptors are present in synaptic and extrasynaptic sites, while NR2A-containing receptors are confined to synaptic sites (Tovar and Westbrook, 1999; Townsend et al., 2003; Scimemi et al., 2004). Other, more recent reports using hippocampal neurons, either in primary cell culture or acute slice, suggest that synaptic and extrasynaptic NMDARs exhibit similar subunit compositions (Thomas et al., 2006; Harris and Pettit, 2007). These discrepancies have yet to be resolved conclusively by anatomical approaches at central synapses.

Here we present ultrastructural and physiological evidence that perisynaptic NMDARs on RGCs are particularly enriched in the NR2B subunit, whereas synaptic NMDARs contain primarily NR2A. These differences are evident in distinct characteristics of sEPSCs (Fig. 9), although it should be noted that current pharmacological tools do not permit specific identification of NR2A NMDARs. The larger functional implications for this distribu- tion pattern remain unknown; more experiments are required to determine whether such distinct subsynaptic expression patterns underlie different dynamics of NMDAR activation and, possibly, dendritic calcium signaling in ON and OFF RGC dendrites.

\section{Different splice variants of the NR1 subunit selectively assemble with NR2 subunits}

It is unclear whether particular NR1 splice variants coassemble preferentially with certain NR2 subunits in the brain. This possibility, suggested by the demonstrated heterogeneity of NMDARs (Sheng et al., 1994) is supported by evidence that ethanol modulates the surface expression of NR1C2' and NR2A (Honse et al., 2003), a subunit combination that is also suggested by our results (Figs. 3, 4), although other biochemical data indicate no preferential NR1/NR2 coassembly (Blahos and Wenthold, 1996; AlHallaq et al., 2001). This discrepancy was attributed to different model systems used in their experiments (Al-Hallaq et al., 2001). Light microscopic studies in rat and primate retina suggested a slight preference of NR2A for NR1C2' over NR1C2 (Fletcher et al., 2000; Gründer et al., 2000), again consistent with the present results, although immunopositive dendrites were not identified in those studies and so could have originated from either RGCs or amacrine cells. In addition to the preferential association of NR1C2' with NR2A in the PSD (Figs. 3, 5), the present results also indicate a strong correlation between the expression of NR1C2 and NR2B in perisynaptic membranes (Figs. 2, 4) and constitute the first ultrastructural anatomical evidence that particular NR1 splice variants specifically colocalize with particular NR2 subunits.

\section{Different NR2 subunits may be anchored by different PDZ scaffolding proteins}

MAGUKs cluster neurotransmitter receptors and ion channels at synaptic sites (Kennedy, 1995; Kornau et al., 1995; Roche et al., 1999; Kim and Sheng, 2004; Elias et al., 2006), but whether certain MAGUKs interact specifically with particular receptor subunits remains controversial. Biochemical and electrophysiological work suggests an apparent preference between NR2A and PSD-95 or PSD-93 and between NR2B and SAP-102 (Valtschanoff et al., 1999; Sans et al., 2000; Losi et al., 2003; Townsend et al., 2003; Prybylowski et al., 2005), but more recent results reveal no preferential interaction between NR2A or NR2B and PSD-95, PSD-93, and SAP102 (Al-Hallaq et al., 2007). Although this has not been explored as thoroughly in the retina, one LM immunofluorescence study did indicate preferential colocalization of NR1C2' and PSD-95 in the IPL of rat (Fletcher et al., 2000). Our results provide the first ultrastructural evidence that NMDA receptor subunits colocalize preferentially with particular MAGUKs in the PSD and at perisynaptic sites. The similar distribution pattern between NR2A subunit and PSD-95/PSD-93 reported here suggests that NR2A colocalizes specifically with PSD-95 and/or PSD-93 at RGC synapses, analogous to previous results in other brain regions (Valtschanoff et al., 1999; Sans et al., 2000; Losi et al., 2003; Prybylowski et al., 2005). Similarly, the identical perisynaptic localization pattern of SAP102 and NR2B subunit also suggests a preferential interaction that is consistent with previous evidence in rat retina showing similar colocalization at the LM level in the IPL (Koulen et al., 1998b) and coimmunoprecipitation results in rat brain (Müller et al., 1996; Sans et al., 2000). The MAGUKs examined here also may underlie targeting of AMPARs (e.g., Roche et al., 1999; Elias et al., 2006), or potassium channels (Kim et al., 1995; Kim and Sheng, 1996; Yazulla and Studholme, 1998). In addition, it remains to be inves- 
tigated whether other proteins that interact with NMDAR subunits-e.g., interactor collapsin receptor mediator protein 2 (GRMP2), which interacts with NR2B (Al-Hallaq et al., 2007)— affect synaptic signaling in RGCs.

\section{Asymmetric distribution of NMDAR subunits and MAGUKs at $\mathrm{ON}$ and OFF RGC synapses}

Numerous studies suggest that different NMDARs play distinct roles in neurotransmission, plasticity, and excitotoxicity (Hardingham et al., 2002; Cull-Candy and Leszkiewicz, 2004; Liu et al., 2004; Massey et al., 2004; Scimemi et al., 2004; Ewald et al., 2008), although recent physiological reports that NR2A and NR2Bcontaining NMDARs contribute specifically to LTP and LTD, respectively (Liu et al., 2004; Massey et al., 2004) have been disputed (Weitlauf et al., 2005; Morishita et al., 2007). In different brain regions, NMDARs mediate distinct inputs to individual neurons. In layer $\mathrm{V}$ cortical pyramidal cells, for example, callosal inputs exhibit a larger NR2A component, whereas intracortical connections are enriched in NR2B (Kumar and Huguenard, 2003). Similar asymmetries have been reported between inputs to pyramidal cells in the CA3 and CA1 regions of the hippocampus (Ito et al., 2000; Kawakami et al., 2003; Arrigoni and Greene, 2004; Wu et al., 2005). Consistent with this trend, the present results suggest that ON inputs to RGCs are mediated mostly by NR2B-containing receptors, whereas OFF inputs are mediated mostly by NR2A receptors (Figs. 4, 5) (see also Kalbaugh et al., 2009). This distinction is echoed clearly in the localization of the NR1 splice variant and MAGUK scaffolding proteins that have been most commonly associated with NR2A: NR1C2', PSD-95, and PSD-93 are expressed more abundantly at OFF synapses (Figs. 5A, $8 A$ ).

In addition to their obviously converse role in visual signaling, $\mathrm{ON}$ and OFF RGCs exhibit asymmetries with regard to receptive field sizes, response kinetics, and contrast sensitivity (Chichilnisky and Kalmar, 2002; Zaghloul et al., 2003). Recent physiological work in the mouse retina suggests that NMDARs are synaptic at OFF RGC synapses and perisynaptic at ON RGC synapses (Sagdullaev et al., 2006), a finding that we confirm anatomically and physiologically in the present study. These distinct subsynaptic NMDAR distributions appear to contribute to different dynamics ranges of light-evoked responses in ON and OFF RGCs (Sagdullaev et al., 2006). Specific roles for particular NR2 subunitcontaining receptors in this process, or in other ON/OFF asymmetries, remain to be explored.

\section{References}

Al-Hallaq RA, Yasuda RP, Wolfe BB (2001) Enrichment of N-methyl-Daspartate NR1 splice variants and synaptic proteins in rat postsynaptic densities. J Neurochem 77:110-119.

Al-Hallaq RA, Conrads TP, Veenstra TD, Wenthold RJ (2007) NMDA diheteromeric receptor populations and associated proteins in rat hippocampus. J Neurosci 27:8334-8343.

Amthor FR, Takahashi ES, Oyster CW (1989) Morphologies of rabbit retinal ganglion cells with complex receptive fields. J Comp Neurol 280:97-121.

Andressen C, Blümcke I, Celio MR (1993) Calcium-binding proteins: selective markers of nerve cells. Cell Tissue Res 271:181-208.

Aoki C, Miko I, Oviedo H, Mikeladze-Dvali T, Alexandre L, Sweeney N, Bredt DS (2001) Electron microscopic immunocytochemical detection of PSD-95, PSD-93, SAP-102, and SAP-97 at postsynaptic, presynaptic, and nonsynaptic sites of adult and neonatal rat visual cortex. Synapse 40:239-257.

Arrigoni E, Greene RW (2004) Schaffer collateral and perforant path inputs activate different subtypes of NMDA receptors on the same CA1 pyramidal cell. Br J Pharmacol 142:317-322.

Blahos J 2nd, Wenthold RJ (1996) Relationship between N-methyl-D- aspartate receptor NR1 splice variants and NR2 subunits. J Biol Chem 271:15669-15674.

Brenman JE, Christopherson KS, Craven SE, McGee AW, Bredt DS (1996) Cloning and characterization of postsynaptic density 93 , a nitric oxide synthase interacting protein. J Neurosci 16:7407-7415.

Chen S, Diamond JS (2002) Synaptically released glutamate activates extrasynaptic NMDA receptors on cells in the ganglion cell layer of rat retina. J Neurosci 22:2165-2173.

Chichilnisky EJ, Kalmar RS (2002) Functional asymmetries in ON and OFF ganglion cells of primate retina. J Neurosci 22:2737-2747.

Clark BA, Cull-Candy SG (2002) Activity-dependent recruitment of extrasynapotic NMDA receptor activation at an AMPA receptor-only synapse. J Neurosci 22:4428-4436.

Clements JD, Bekkers JM (1997) Detection of spontaneous synaptic events with an optimally scaled template. Biophys J 73:220-229.

Collingridge GL, Lester RA (1989) Excitatory amino acid receptors in the vertebrate central nervous system. Pharmacol Rev 41:143-210.

Cull-Candy SG, Leszkiewicz DN (2004) Role of distinct NMDA receptor subtypes at central synapses. Sci STKE 2004:re16.

Davies C, Tingley D, Kachar B, Wenthold RJ, Petralia RS (2001) Distribution of members of the PSD-95 family of MAGUK proteins at the synaptic region of inner and outer hair cells of the guinea pig cochlea. Synapse 40:258-268.

Dingledine R, Borges K, Bowie D, Traynelis SF (1999) The glutamate receptor ion channels. Pharmacol Rev 51:7-61.

El-Husseini AE, Topinka JR, Lehrer-Graiwer JE, Firestein BL, Craven SE, Aoki C, Bredt DS (2000) Ion channel clustering by membraneassociated guanylate kinases. Differential regulation by N-terminal lipid and metal binding motifs. J Biol Chem 275:23904-23910.

Elias GM, Funke L, Stein V, Grant SG, Bredt DS, Nicoll RA (2006) Synapsespecific and developmentally regulated targeting of AMPA receptors by a family of MAGUK scaffolding proteins. Neuron 52:307-320.

Ewald RC, Van Keuren-Jensen KR, Aizenman CD, Cline HT (2008) Roles of NR2A and NR2B in the development of dendritic arbor morphology in vivo. J Neurosci 28:850-861.

Fletcher EL, Hack I, Brandstätter JH, Wässle H (2000) Synaptic localization of NMDA receptor subunits in the rat retina. J Comp Neurol 420:98-112.

Goebel DJ, Aurelia JL, Tai Q, Jojich L, Poosch MS (1998) Immunocytochemical localization of the NMDA-R2A receptor subunit in the cat retina. Brain Res 808:141-154.

Gründer T, Kohler K, Kaletta A, Guenther E (2000) The distribution and developmental regulation of NMDA receptor subunit proteins in the outer and inner retina of the rat. J Neurobiol 44:333-342.

Hardingham GE, Fukunaga Y, Bading H (2002) Extrasynaptic NMDARs oppose synaptic NMDARs by triggering CREB shut-off and cell death pathways. Nat Neurosci 5:405-414.

Harris AZ, Pettit DL (2007) Extrasynaptic and synaptic NMDA receptors form stable and uniform pools in rat hippocampal slices. J Physiol 584:509-519.

Hartveit E, Brandstätter JH, Sassoè-Pognetto M, Laurie DJ, Seeburg PH, Wässle H (1994) Localization and developmental expression of the NMDA receptor subunit NR2A in the mammalian retina. J Comp Neurol 348:570-582.

Hollmann M, Boulter J, Maron C, Beasley L, Sullivan J, Pecht G, Heinemann S (1993) Zinc potentiates agonist-induced currents at certain splice variants of the NMDA receptor. Neuron 10:943-954.

Honse Y, Nixon KM, Browning MD, Leslie SW (2003) Cell surface expression of NR1 splice variants and NR2 subunits is modified by prenatal ethanol exposure. Neuroscience 122:689-698.

Ishii T, Moriyoshi K, Sugihara H, Sakurada K, Kadotani H, Yokoi M, Akazawa C, Shigemoto R, Mizuno N, Masu M, Nakanishi S (1993) Molecular characterization of the family of the $N$-methyl-D-aspartate receptor subunits. J Biol Chem 268:2836-2843.

Ito I, Kawakami R, Sakimura K, Mishina M, Sugiyama H (2000) Inputspecific targeting of NMDA receptor subtypes at mouse hippocampal CA3 pyramidal neuron synapses. Neuropharmacology 39:943-951.

Kalbaugh TL, Zhang J, Diamond JS (2009) Coagonist release modulates NMDA receptor subtype contributions at synaptic inputs to retinal ganglion cells. J Neurosci 29:1469-1479.

Kalloniatis M, Sun D, Foster L, Haverkamp S, Wässle H (2004) Localization of NMDA receptor subunits and mapping NMDA drive within the mammalian retina. Vis Neurosci 21:587-597. 
Kawakami R, Shinohara Y, Kato Y, Sugiyama H, Shigemoto R, Ito I (2003) Asymmetrical allocation of NMDA receptor epsilon2 subunits in hippocampal circuitry. Science 300:990-994.

Kennedy MB (1995) Origin of PDZ (DHR, GLGF) domains. Trends Biochem Sci 20:350.

Kim E, Sheng M (1996) Differential K+ channel clustering activity of PSD-95 and SAP97, two related membrane-associated putative guanylate kinases. Neuropharmacology 35:993-1000.

Kim E, Sheng M (2004) PDZ domain proteins of synapses. Nat Rev Neurosci 5:771-781.

Kim E, Niethammer M, Rothschild A, Jan YN, Sheng M (1995) Clustering of Shaker-type $\mathrm{K}+$ channels by interaction with a family of membraneassociated guanylate kinases. Nature 378:85-88.

Kornau HC, Schenker LT, Kennedy MB, Seeburg PH (1995) Domain interaction between NMDA receptor subunits and the postsynaptic density protein PSD-95. Science 269:1737-1740.

Koulen P (1999) Localization of synapse-associated proteins during postnatal development of the rat retina. Eur J Neurosci 11:2007-2018.

Koulen P, Fletcher EL, Craven SE, Bredt DS, Wässle H (1998a) Immunocytochemical localization of postsynaptic density protein PSD-95 in the mammalian retina. J Neurosci 18:10136-10149.

Koulen P, Garner CC, Wässle H (1998b) Immunocytochemical localization of the synapse-associated protein SAP102 in the rat retina. J Comp Neurol 397:326-336.

Kumar SS, Huguenard JR (2003) Pathway-specific differences in subunit composition of synaptic NMDA receptors on pyramidal neurons in neocortex. J Neurosci 23:10074-10083.

Lin JW, Wyszynski M, Madhavan R, Sealock R, Kim JU, Sheng M (1998) Yotiao, a novel protein of neuromuscular junction and brain that interacts with specific splice variants of NMDA receptor subunit NR1. J Neurosci 18:2017-2027.

Liu L, Wong TP, Pozza MF, Lingenhoehl K, Wang Y, Sheng M, Auberson YP, Wang YT (2004) Role of NMDA receptor subtypes in governing the direction of hippocampal synaptic plasticity. Science 304:1021-1024.

Losi G, Prybylowski K, Fu Z, Luo J, Wenthold RJ, Vicini S (2003) PSD-95 regulates NMDA receptors in developing cerebellar granule neurons of the rat. J Physiol 548:21-29.

Massey PV, Johnson BE, Moult PR, Auberson YP, Brown MW, Molnar E, Collingridge GL, Bashir ZI (2004) Differential roles of NR2A and NR2B-containing NMDA receptors in cortical long-term potentiation and long-term depression. J Neurosci 24:7821-7828.

Matsui K, Hosoi N, Tachibana M (1998) Excitatory synaptic transmission in the inner retina: paired recordings of bipolar cells and neurons of the ganglion cell layer. J Neurosci 18:4500-4510.

McIlhinney RA, Le Bourdellès B, Molnár E, Tricaud N, Streit P, Whiting PJ (1998) Assembly intracellular targeting and cell surface expression of the human N-methyl-D-aspartate receptor subunits NR1a and NR2A in transfected cells. Neuropharmacology 37:1355-1367.

McIlhinney RA, Philipps E, Le Bourdelles B, Grimwood S, Wafford K, Sandhu S, Whiting P (2003) Assembly of $N$-methyl-D-aspartate (NMDA) receptors. Biochem Soc Trans 31:865-868.

Migaud M, Charlesworth P, Dempster M, Webster LC, Watabe AM, Makhinson M, He Y, Ramsay MF, Morris RG, Morrison JH, O’Dell TJ, Grant SG (1998) Enhanced long-term potentiation and impaired learning in mice with mutant postsynaptic density-95 protein. Nature 396:433-439.

Mittman S, Taylor WR, Copenhagen DR (1990) Concomitant activation of two types of glutamate receptor mediates excitation of salamander retinal ganglion cells. J Physiol 428:175-197.

Momiyama A (2000) Distinct synaptic and extrasynaptic NMDA receptors identified in dorsal horn neurones of the adult rat spinal cord. J Physiol 523:621-628.

Monyer H, Burnashev N, Laurie DJ, Sakmann B, Seeburg PH (1994) Developmental and regional expression in the rat brain and functional properties of four NMDA receptors. Neuron 12:529-540.

Morishita W, Lu W, Smith GB, Nicoll RA, Bear MF, Malenka RC (2007) Activation of NR2B-containing NMDA receptors is not required for NMDA receptor-dependent long-term depression. Neuropharmacology 52:71-76.

Müller BM, Kistner U, Veh RW, Cases-Langhoff C, Becker B, Gundelfinger ED, Garner CC (1995) Molecular characterization and spatial distribution of SAP97, a novel presynaptic protein homologous to SAP90 and the
Drosophila discs-large tumor suppressor protein. J Neurosci 15:2354-2366.

Müller BM, Kistner U, Kindler S, Chung WJ, Kuhlendahl S, Fenster SD, Lau LF, Veh RW, Huganir RL, Gundelfinger ED, Garner CC (1996) SAP102, a novel postsynaptic protein that interacts with NMDA receptor complexes in vivo. Neuron 17:255-265.

Nelson R, Famiglietti EV Jr, Kolb H (1978) Intracellular staining reveals different levels of stratification for on- and off-center ganglion cells in cat retina. J Neurophysiol 41:472-483.

Nusser Z, Roberts JD, Baude A, Richards JG, Somogyi P (1995) Relative densities of synaptic and extrasynaptic $\mathrm{GABA}_{\mathrm{A}}$ receptors on cerebellar granule cells as determined by a quantitative immunogold method. J Neurosci 15:2948-2960.

Peichl L, Wässle H (1981) Morphological identification of on- and offcentre brisk transient $(\mathrm{Y})$ cells in the cat retina. Proc R Soc Lond B Biol Sci 212:139-153.

Peters A, Palay S, Webster H (1991) The fine structure of the nervous system: neurons and their supporting cells, Ed 3. New York: Oxford UP.

Petralia RS, Wang YX, Wenthold RJ (1994) The NMDA receptor subunits NR2A and NR2B show histological and ultrastructural location patterns similar to those of NR1. J Neurosci 10:6102-6120.

Prybylowski K, Chang K, Sans N, Kan L, Vicini S, Wenthold RJ (2005) The synaptic localization of NR2B-containing NMDA receptors is controlled by interactions with PDZ proteins and AP-2. Neuron 47:845-857.

Rivera N, Lugo N (1998) Four retinal ganglion cell types that project to the superior colliculus in the thirteen-lined ground squirrel (Spermophilus tridecemlineatus). J Comp Neurol 396:105-120.

Roche KW, Ly CD, Petralia RS, Wang YX, McGee AW, Bredt DS, Wenthold RJ (1999) Postsynaptic density-93 interacts with the $\delta 2$ glutamate receptor subunit at parallel fiber synapses. J Neurosci 19:3926-3934.

Rumbaugh G, Vicini S (1999) Distinct synaptic and extrasynaptic NMDA receptors in developing cerebellar granule neurons. J Neurosci 19:10603-10610.

Sagdullaev BT, McCall MA, Lukasiewicz PD (2006) Presynaptic inhibition modulates spillover, creating distinct dynamic response ranges of sensory output. Neuron 50:923-935.

Sans N, Petralia RS, Wang YX, Blahos J 2nd, Hell JW, Wenthold RJ (2000) A developmental change in NMDA receptor-associated proteins at hippocampal synapses. J Neurosci 20:1260-1271.

Sassoé-Pognetto M, Ottersen OP (2000) Organization of ionotropic glutamate receptors at dendrodendritic synapses in the rat olfactory bulb. J Neurosci 20:2192-2201.

Schneggenburger R, Zhou Z, Konnerth A, Neher E (1993) Fractional contribution of calcium to the cation current through glutamate receptor channels. Neuron 11:133-143.

Scimemi A, Fine A, Kullmann DM, Rusakov DA (2004) NR2B-containing receptors mediate cross talk among hippocampal synapses. J Neurosci 24:4767-4777.

Sheng M, Cummings J, Roldan LA, Jan YN, Jan LY (1994) Changing subunit composition of heteromeric NMDA receptors during development of rat cortex. Nature 368:144-147.

Steigerwald F, Schulz TW, Schenker LT, Kennedy MB, Seeburg PH, Köhr G (2000) C-terminal truncation of NR2A subunits impairs synaptic but not extrasynaptic localization of NMDA receptors. J Neurosci 20:4573-4581.

Stocca G, Vicini S (1998) Increased contribution of NR2A subunit to synaptic NMDA receptors in developing rat cortical neurons. J Physiol 507:13-24.

Thomas CG, Miller AJ, Westbrook GL (2006) Synaptic and extrasynaptic NMDA receptor NR2 subunits in cultured hippocampal neurons. J Neurophysiol 95:1727-1734.

Thompson CL, Drewery DL, Atkins HD, Stephenson FA, Chazot PL (2000) Immunohistochemical localization of $N$-methyl-D-aspartate receptor NR1, NR2A, NR2B and NR2C/D subunits in the adult mammalian cerebellum. Neurosci Lett 283:85-88.

Tovar KR, Westbrook GL (1999) The incorpation of NMDA receptors with a distinct subunit composition at nascent hippocampal synapses in vitro. J Neurosci 19:4180-4188.

Townsend M, Yoshii A, Mishina M, Constantine-Paton M (2003) Developmental loss of miniature $N$-methyl-D-aspartate receptor currents in NR2A knockout mice. Proc Natl Acad Sci U S A 100:1340-1345. 
Valtschanoff JG, Burette A, Wenthold RJ, Weinberg RJ (1999) Expression of NR2 receptor subunit in rat somatic sensory cortex: synaptic distribution and colocalization with NR1 and PSD-95. J Comp Neurol 410:599-611.

Weitlauf C, Honse Y, Auberson YP, Mishina M, Lovinger DM, Winder DG (2005) Activation of NR2A-containing NMDA receptors is not obligatory for NMDA receptor-dependent long-term potentiation. J Neurosci 25:8386-8390.

Werblin FS, Dowling JE (1969) Organization of the retina of the mudpuppy, Necturus maculosus. II. Intracellular recording. J Neurophysiol 32:339-355.

Wu Y, Kawakami R, Shinohara Y, Fukaya M, Sakimura K, Mishina M, Watanabe M, Ito I, Shigemoto R (2005) Target-cell-specific left-right asym- metry of NMDA receptor content in Schaffer collateral synapses in $\varepsilon 1 /$ NR2A knock-out mice. J Neurosci 25:9213-9226.

Yazulla S, Studholme KM (1998) Differential distribution of Shaker-like and Shab-like $\mathrm{K}+$-channel subunits in goldfish retina and retinal bipolar cells. J Comp Neurol 396:131-140.

Zaghloul KA, Boahen K, Demb JB (2003) Different circuits for ON and OFF retinal ganglion cells cause different contrast sensitivities. J Neurosci 23:2645-2654.

Zhang J, Diamond JS (2006) Distinct perisynaptic and synaptic localization of NMDA and AMPA receptors on ganglion cells in rat retina. J Comp Neurol 498:810-820.

Zukin RS, Bennett MV (1995) Alternatively spliced isoforms of the NMDARI receptor subunit. Trends Neurosci 18:306-313. 